\title{
Fates of Neurotrophins after Retrograde Axonal Transport: Phosphorylation of p75NTR Is a Sorting Signal for Delayed Degradation
}

\author{
Rafal Butowt and Christopher S. von Bartheld \\ Department of Physiology and Cell Biology, University of Nevada School of Medicine, Reno, Nevada 89557
}

\begin{abstract}
Neurotrophins can mediate survival or death of neurons. Opposing functions of neurotrophins are based on binding of these ligands to two distinct types of receptors: trk receptors and p75NTR. Previous work showed that target-derived NGF induces cell death, whereas BDNF and NT-3 enhance survival of neurons in the isthmo-optic nucleus of avian embryos. To determine the fate of retrogradely transported neurotrophins and test whether their sorting differs between neurotrophins mediating survival- or death-signaling pathways, we traced receptor-binding, sorting, and degradation kinetics of target-applied radiolabeled neurotrophins that bind in this system to trk receptors (BDNF, NT-3) or only to p75NTR (NGF). At the ultrastructural level, the p75NTRbound NGF accumulates with a significant delay in multivesicular bodies and organelles of the degradation pathway on arrival in the cell body when compared with trk-bound BDNF or NT-3. This delayed lysosomal accumulation was restricted to target-derived NGF, but was not seen when NGF was supplied to the soma in vitro. The kinase inhibitors K252a and Gö6976 alter the kinetics of organelle accumulation: phosphorylation of p75NTR is a sorting signal for delayed sequestering of p75NTR-bound NGF in multivesicular bodies and delayed degradation in lysosomes when compared with trk-bound neurotrophins. Mutagenesis and mass spectrometry studies indicate that p75NTR is phosphorylated by conventional protein kinase $\mathrm{C}$ on serine 266 . We conclude that, in addition to the known phosphorylation of trks, the phosphorylation of p75NTR can also significantly affect neuronal survival in vivo by changing the intracellular sorting and degradation kinetics of its ligands and thus signaling duration.
\end{abstract}

\section{Introduction}

Retrograde axonal transport of neurotrophic factors is a cornerstone of the neurotrophic hypothesis. Transport of these signaling molecules is believed to be essential for the survival of developing neurons (Purves, 1988; Barde, 1989; Zweifel et al., 2005; Oppenheim and von Bartheld, 2008). One of the most important families of neurotrophic factors, the neurotrophins, can mediate survival signals as well as death signals, depending on the type of receptor: trk receptors versus the "common" neurotrophin receptor, p75NTR (Chao and Hempstead, 1995; Carter and Lewin, 1997; Frade and Barde, 1998; Dechant and Barde, 2002). Despite considerable research on the molecular and cell biology of neurotrophin sorting and signaling (Hibbert et al., 2006; Bronfman et al., 2007), little is known about the interactions of neurotrophins and their receptors during axonal trans-

\footnotetext{
Received May 29, 2009; revised July 15, 2009; accepted July 20, 2009.

This work was supported by National Institutes of Health Grants NS35931 and EY12841 (C.S.v.B.), TW05700 (C.S.v.B., R.B.), and NS47216 (R.B., C.S.v.B.). The Proteomics and Genomics Centers and the Transmission Electron Microscopy Facility at University of Nevada, Reno are supported by IDeA Network of Biomedical Research Excellence Grant P20 RR01643. We thank Eric S. Guglielmo, Shayda Movahedi, and Larisa Wiggins (Baryshnikova) for expert technical assistance, and Peter Clarke and Mark Bothwell for critical comments. Chicken neurotrophin receptorspecific antibodies were kindly provided by Louis Reichardt's Laboratory (University of California, San Francisco, San Francisco, (A). The trophic factors BDNF, NT-3, and NT-4 were generously provided by Regeneron.

Correspondence should be addressed to Christopher S. von Bartheld, Department of Physiology and Cell Biology, Mailstop 352, University of Nevada School of Medicine, Reno, NV 89557. E-mail: cvonbartheld@medicine.nevada.edu. D0I:10.1523/JNEUROSCI.2512-09.2009

Copyright $\odot 2009$ Society for Neuroscience $\quad$ 0270-6474/09/2910715-15\$15.00/0
}

port and the mechanisms that sort these molecules on arrival in the cell body in vivo. It is not known whether death-signaling neurotrophins and their receptors transit through different organelles than survival-signaling neurotrophins, or what kind of mechanisms sort neurotrophins and their receptors into degradation or recycling pathways. Altering the signal duration by degrading receptors or ligands may have as profound influences on signaling as speed or onset of signaling, but has received less attention (Wan et al., 2008). Signaling is regulated by parameters that include, in other systems, phosphorylation (Felder et al., 1990; Alvi et al., 2007) as well as kinetics of signal transduction with either brief or sustained activation of kinases (Traverse et al., 1992; Marshall, 1995). No such direct comparisons have yet been made, in vivo, for trk-bound and p75NTR-bound ligands.

To elucidate mechanisms of retrograde neurotrophin sorting and signaling, we used a particularly advantageous in vivo model system, the isthmo-optic nucleus (ION). The ION innervates a subtype of amacrine cells in the avian retina and undergoes substantial developmental cell death (Clarke, 1992). Importantly, this cell death is regulated by neurotrophins that are retrogradely transported from the retina to the ION (von Bartheld et al., 1994, 1996b; Primi and Clarke, 1996; Janiga et al., 2000). NGF and NT-4 kill developing ION neurons, whereas BDNF and NT-3 enhance survival (von Bartheld et al., 1994; Primi and Clarke, 1996; Janiga et al., 2000). By injecting radiolabeled neurotrophins into the eye, we traced the subcellular fate and functions of the neurotrophins and their receptors in this in vivo model system. 
The combination of cell biological, biochemical, molecular, and ultrastructural approaches indicates that (1) a major fraction of the neurotrophin BDNF appears to translocate from p75NTRs to trkB receptors during or after retrograde axonal transport; (2) sorting of axonally transported p75NTR-bound neurotrophins into the lysosomal degradation pathway is delayed compared with neurotrophins bound to trk receptors; (3) phosphorylation of p75NTR constitutes a sorting signal that significantly delays ligand sequestering and degradation; (4) inhibition of phosphorylation of p75NTR causes changes in the dynamics and turnover of its ligands, and thereby has a significant effect on the survival of developing neurons. Preliminary data of this work have been presented (von Bartheld et al., 2004).

\section{Materials and Methods}

Sources of materials. Chicken eggs were obtained from California Golden Eggs and were incubated in humidified chambers at $37.5-38^{\circ} \mathrm{C}$. Approximately 2200 chicken eggs were used. The ages of chick embryos were verified at the time of killing by staging according to Hamburger and Hamilton (1951). Experimental procedures were conducted in compliance with the Society for Neuroscience Policy on the Use of Animals in Neuroscience Research and were approved by the local animal care committee. Polyclonal antibodies against chicken p75NTR, trkA, trkB, or trkC (all against the extracellular domain) were from the Reichardt Laboratory (Weskamp and Reichardt, 1991; Lefcort et al., 1996; von Bartheld et al., 1996b). NGF was purchased from Promega, and BDNF, NT-3, and NT-4 were provided by Regeneron. K252a (CAS No. 97161-97-2) was from Alomone Labs and Gö6976 was obtained from Alexis Biochemicals. ${ }^{125} \mathrm{I}-\mathrm{Na}$ was from PerkinElmer Life and Analytical Sciences, L4 autoradiography emulsion was from Ilford. Protein kinase C catalytic subunit was from Calbiochem. Microscopy materials were from Ted Pella or (Electron Microscopy Sciences), and other materials were from SigmaAldrich (if not indicated otherwise).

Radioiodination and methods for in vivo intraocular injections. Neurotrophins were iodinated with lactoperoxidase as described previously (von Bartheld, 2001). Incorporations were 77-95\% (NGF), 90-96\% (BDNF), 81-95\% (NT-3), and 59-92\% (NT-4). Specific activities were 65-110 cpm/pg of NGF, $92-189 \mathrm{cpm} / \mathrm{pg}$ of BDNF, 77-193 cpm/pg of NT-3, and $126-264 \mathrm{cpm} / \mathrm{pg}$ of NT-4. Iodinated neurotrophins $(\sim 100-$ $200 \mathrm{ng} ; \sim 10-20$ million cpm) were injected in volumes of $4-6 \mu$ linto the vitreous of the eye of embryos at ages embryonic day 14 (E14) to E15 using disposable insulin syringes. For experiments with kinase inhibitors, neurotrophins $(4 \mu \mathrm{l})$ were coinjected with $\mathrm{K} 252 \mathrm{a}(1 \mu \mathrm{l}$ of $250 \mu \mathrm{M}$ in DMSO), with 12-(2-cyanoethyl)-6,7,12,13-tetrahydro-13-methyl-5-oxo$5 H$-indolo[2,3-a]pyrrolo[3,4-c] carbazole (Gö6976) $(1 \mu \mathrm{l}$ of $250 \mu \mathrm{M}$ in DMSO), with genistein ( $2 \mu \mathrm{l}$ of $1 \mathrm{~mm}$ in DMSO), or with calphostin $\mathrm{C}(1 \mu \mathrm{l}$ of $500 \mu \mathrm{M}$ in DMSO). Control embryos were injected with neurotrophins in $1 \mu \mathrm{l}$ of DMSO or with $9 \mu \mathrm{g}$ of monensin. Ten, 20 , or $32 \mathrm{~h}$ after injection, the embryos were anesthetized with Nembutal, perfused with fixative for electron microscopy (see below) or with PBS for immunoprecipitation (see below), and staged. The amounts of radioactivity in the dissected eyes and IONs were measured in a gamma counter (PerkinElmer Wallac 1470 Wizard). Radioactivity visualized as silver grains in ION neurons likely represents intact neurotrophin, because a significant fraction of radioactivity recovered from the ION after retrograde axonal transport is intact protein as shown by SDS-PAGE (von Bartheld and Johnson, 2001).

Internalization of radiolabeled neurotrophins by ION neurons in vitro. Chick embryos at ages E14-E15 were decapitated, and slices through the ION were collected in cold PBS. The ION was dissected from slices and placed in F12/DEM medium in a volume of $100 \mu$ l. Radiolabeled NGF or $\mathrm{BDNF}$ (40 ng) was added and the IONs were incubated for $1-4 \mathrm{~h}$ at $37^{\circ} \mathrm{C}$. In some cases, protein kinase C (PKC) catalytic subunit (40 ng) was added with or without Chariot pretreatment according to the manufacturer's protocol. Tubes were gamma counted, and tissue samples containing the ION were fixed in cacodylate buffer containing $2 \%$ glutaraldehyde and processed and embedded for resin embedding as described below. Before sectioning, samples were gamma counted again.
IONs typically retained $\sim 20-100 \mathrm{pg}$ of the neurotrophin. Thin sections were collected on grids and coated with a monolayer of emulsion as described above. Emulsion-coated sections were developed after 2-3 months, and triplicate samples for each condition were analyzed for lysosome and multivesicular body (MVB) distribution of silver grains within ION cell bodies, with 134-260 silver grains analyzed per data point. Student's $t$ test was used to compare conditions (NGF, BDNF) for the different time points.

Measurement of speed of neurotrophin transport to the ION. For the determination of any possible differences between the time of arrival of retrograde NGF and BDNF after axonal transport from the eye to the ION, 59 chick embryos were successfully injected at E14-E15.5 with either radiolabeled NGF or BDNF $\left(\sim 20 \times 10^{6} \mathrm{cpm}=200 \mathrm{ng}\right)$, and were anesthetized and perfusion-fixed with $4 \%$ paraformaldehyde after 2, 5, $10,15,20,25$, or $30 \mathrm{~h}$. Embryos were staged, the eyes and brains dissected, and eyes counted in a gamma counter to verify successful injections. The brains were postfixed and the midbrains and brainstems were serially sectioned in the transverse plane at $500 \mu \mathrm{m}$ on a vibratome (series 1000). From these slices, the left and right IONs were dissected as described previously (von Bartheld and Johnson, 2001), and each ION slice was gamma counted. The cpm amounts of the slices containing parts of the ION were added. The mean and SE of the cpm for each treatment group, after subtraction of the background, were compared by unpaired twotailed $t$ test for statistical significance between NGF and BDNF accumulation for each transport interval.

Cross-linking and immunoprecipitation. Chick embryos at E15 were injected with 25-50 ng of radiolabeled NGF or BDNF in the eye in ovo. Twenty hours later, the animals were anesthetized with Nembutal and transcardially perfused with cold PBS. The optic chiasm and the contralateral ION were dissected, collected in PBS, and homogenized in lysis buffer using 22 gauge needles. Lysis buffer consisted of $50 \mathrm{~mm}$ Tris- $\mathrm{HCl}$ at $\mathrm{pH} 6.5$ for cross-linking with 1-ethyl-3-[3-dimethylaminopropyl]carbodiimide hydrochloride (EDC), or at $\mathrm{pH} 7.6$ for cross-linking with disuccinimidyl suberate (DSS), and in addition contained $150 \mathrm{~mm} \mathrm{NaCl}, 1 \%$ Triton X-100, $100 \mu \mathrm{g} / \mathrm{ml}$ aprotinin, $1 \mu \mathrm{g} / \mathrm{ml}$ leupeptin, and $0.5 \mathrm{~mm}$ PMSF. One of the two cross-linkers was added to the homogenates for $30 \mathrm{~min}$ at room temperature in a rotating device; EDC (Pierce Chemical) at $6 \mathrm{~mm}, \mathrm{pH}$ 6.5, or DSS (Pierce) at $0.1 \mathrm{~mm}, \mathrm{pH}$ 7.6. The cross-linking reaction was terminated by incubation in cold PBS containing $50 \mathrm{~mm}$ lysine for $30 \mathrm{~min}$. The preparation was centrifuged for $5-10 \mathrm{~min}$ at $4^{\circ} \mathrm{C}$, and pellets and supernatants were counted separately in a gamma counter. Usually $70-80 \%$ of total counts were retained in the supernatant. The supernatant was incubated overnight at $4^{\circ} \mathrm{C}$ with $1.4-1.7 \mu \mathrm{g} / \mathrm{ml}$ polyclonal antibodies against chicken p75NTR, trkB, or trkC, or the same concentration of normal rabbit IgG as control. The next day, 10-20 $\mu \mathrm{l}$ of washed Pansorbin cells (Calbiochem) were added for $1 \mathrm{~h}$ in the cold room, the immunocomplex was pelleted by centrifugation for $5 \mathrm{~min}$ in the cold room, and the pellets and supernatants were counted separately in a gamma counter. All determinations were done in triplicate. Nonspecific precipitation was subtracted by using the counts from the control (IgG-incubated) pellets. We are using the terminology "specific precipitation" to indicate that the antibodies were precipitating their antigens specifically. These particular experiments did not test whether binding of the neurotrophin was "specific" (i.e., competed by excess cold: receptor bound). Control experiments included the following: (1) incubation of normal lysed tissues with similar amounts of radiolabeled BDNF to assess whether free BDNF may bind to different receptors when they become available during lysis, (2) omission of the cross-linking step, and (3) repeated immunoprecipitation of the same supernatants to determine the efficiency with which the antibodies pulled down the receptors. Statistical significance was determined by unpaired two-tailed $t$ test.

Autoradiography at the electron microscopic level. Quantitative electron microscopic autoradiography was performed as previously described in detail (Butowt and von Bartheld, 2001; von Bartheld, 2001; Rind et al., 2005). In short, IONs from E15 embryos were dissected and fixed for $8 \mathrm{~h}$ at $4^{\circ} \mathrm{C}$ in $2 \%$ paraformaldehyde $/ 2 \%$ glutaraldehyde in $0.1 \mathrm{M}$ phosphate buffer, $\mathrm{pH} 7.5$, or transferred from in vitro incubations as described above, and postfixed in $1 \% \mathrm{OsO}_{4}$ in $0.05 \mathrm{~m}$ sodium cacodylate buffer, $\mathrm{pH}$ 7.4, and subsequently embedded in Spurr resin (Electron Microscopy 
Sciences). Resin-embedded IONs were gamma counted, and ultrathin sections $(90 \mathrm{~nm})$ were collected on copper grids (300 mesh) and coated with a monolayer of diluted Ilford L4 emulsion using the "loop method." After 2-3 months of exposure, the grids were developed in D19 (Kodak), fixed, and stained with $2.5 \%$ aqueous lead citrate. ION neurons were examined and photographed or scanned in a Phillips CM10 transmission electron microscope equipped with a Gatan 792 BioScan digital imaging system. The background level of silver grains was determined by photographing six random areas containing resin only, at a magnification of $5000 \times$. Background levels were consistently negligible over individual grids. From each grid, three to four squares containing ION neurons were analyzed and all silver grains were photographed at a magnification of $11,000 \times$. Free ${ }^{125} \mathrm{I}$ is not transported retrogradely from the eye to the ION and did not accumulate over cellular organelles within the ION. The circle probability method with a half-distance (HD) of $90 \mathrm{~nm}$ (von Bartheld, 2001) was used to analyze and quantify the source of grains. Quantification was restricted to ION somata; neurites and growth cones were not considered in this study. Using a transparent grid, the average area occupied by particular organelles ("fractional area") was determined by morphometric analysis at $11,000 \times$ magnification. The "labeling density" (LD) of organelles was determined by dividing the percentage of silver grains found over organelles by the percentage of the fractional area of that organelle. A labeling density $\leq 1$ indicates that silver grains were distributed randomly, whereas LDs much greater than 1.0 indicate a specific association of silver grains with this organelle. The silver grains for each treatment group (each experimental condition examined) were assigned randomly to two groups, and unpaired two-tailed $t$ test was used to determine whether LDs in the NGF group were significantly different $(p<0.05)$ from LDs in the BDNF/NT-3 group. When multiple groups were compared for statistically significant differences, the Bonferroni correction was applied. We identified organelles according to the criteria by Peters et al. (1991). To confirm the identity of organelles scored as lysosomes, acid phosphatase enzyme histochemistry was performed as previously described (Altick et al., 2009).

Total RNA purification, cDNA synthesis, and PCR. The ION was labeled retrogradely by intraocular injection of the lipophilic dye DiI (1-2\% in $100 \%$ ethanol; Invitrogen) and dissected under an inverted fluorescence microscope (von Bartheld and Johnson, 2001). For each individual experiment, the total RNA from two to three IONs was extracted. Total RNA was extracted using Trizol reagent (Invitrogen) or NucleoSpin RNA II kit (BD Biosciences) according to the manufacturer's recommended procedure with some modifications. The $5 \mu \mathrm{g}$ of RNAfree glycogen was added as a carrier, and for the Trizol protocol, additional acid phenol/chloroform extraction was included. In the case of NucleoSpin reagent, a DNase digestion step was performed "on the column," and when Trizol reagent was used, the DNase digestion was performed in solution (DNase I; Promega) followed by phenol/chloroform extraction and ethanol precipitation. Reverse transcription reactions were performed in a $10 \mu \mathrm{l}$ volume using SuperScript III and random hexamer primers according to the manufacturer's protocol (Invitrogen). Relative expression of p75NTR, trkA, trkB, and trkC in the ION was compared at age E15 using real-time PCR technique with SYBR Green I as a DNA binding dye. All real-time PCR experiments were performed three times using ABI5700 apparatus in triplicate per plate with $2 \times$ SYBR Green master mix (Applied Biosystems). Program parameters (annealing $T$ at $60^{\circ} \mathrm{C}$ ) and cycle numbers (40) were as recommended by Applied Biosystems. For control reactions, template or appropriate primers were omitted and "-RT" cDNA was used. Oligonucleotide primers used were designed by PrimerQuest (Integrated DNA Technologies) and synthesized by Integrated DNA Technologies. The quality of oligonucleotides was examined by melting curve analysis, and validation experiments were performed for each primer pair. The absolute quantification for each receptor was achieved using the standard curve method, plotting threshold cycle $(\mathrm{Ct})$ values against the logarithm of known gene copy number for each receptor. The dissected IONs used for each independent experiment were analyzed separately for the expression of all four receptors, thus the amount of tissue, the amount of RNA, and the efficiency of cDNA synthesis did not influence the relative ratio of expression between these receptors. Subsequently, the expression of trkB was set to be $=1$ (calibrator), and the expression of p75NTR, trkC, and trkA was calculated relative to the expression of the calibrator. Primers used were as follows: p75NTR-F, 5'-CTGTTGGCAGAGCAAGGACT-3', p75NTR-R, 5'-ATCCACGCCAGACGTAGAAA-3' (product size, 204 bp); trkA-F, 5' -GGAGCTTGTCCTGGAGATCA-3', trkA-R, 5'-GAGCCATTGAAGAGCCAAAG-3' (product size, $228 \mathrm{bp}$ ); trkB-F, 5' -CTGTGGTGGAAGGAAAGAGC-3', trkB-R, 5' -ATACCGTCAGTTCGGCAGAG-3' (product size, $231 \mathrm{bp}$ ); trkC-F, 5'-AGTCTGCCCCAAGGAGGTAT- ${ }^{\prime}$ ' trkC-R, 5' -GAAGGAAGGACGGAAGGAAG-3' (product size, $191 \mathrm{bp}$ ).

Cloning of the full-length chicken p75NTR receptor. The chicken p75 common neurotrophin receptor (p75NTR) was first cloned by Large et al. (1989). However, the cDNA sequence was never available through GenBank, which limits its use for primer design and molecular analysis. To express full-length chicken p75NTR in cell cultures for mass spectrometry analysis, we cloned this gene using PCR strategy. Total RNA from embryonic retinas at age E15 was purified as indicated above using Trizol reagents, and cDNA was synthesized using SuperScript III reverse transcriptase (Invitrogen). Several primer pairs were designed to cover the entire p75NTR sequence and PCR amplification $\left(30\right.$ cycles, $94^{\circ} \mathrm{C}$, $30 \mathrm{~s} ; 60^{\circ} \mathrm{C}, 50 \mathrm{~s} ; 72^{\circ} \mathrm{C}, 60 \mathrm{~s}$ ) was performed using Advantage HD high fidelity DNA polymerase mix (Clontech). The PCR products were subcloned into pGEM-Teasy vector and sequenced using SP6 and T7 primers. The resulting cDNA sequence for chicken p75NTR is available through GenBank under accession number EU282004. The following primers were used: F1, 5' -ACAGCTGCAAGCAGAACAAGCA-3', R1, 5' TGCATACAGGGCCATAAAGCGA-3'; F2, 5' ${ }^{\prime}$-TCTCGGATGAGGCCAATTTCGT-3', R2, 5' -TGCTTGCAGCTGTTCCACCTTT-3'; F3, 5' -ACTAAGATGTACACGACGAGCGGT-3'， R3，5'-ACTCCTTCACCATCACCTCGTTCT-3'; F4, 5' -TGAGTGCTGCAAAGCCTGCAA-3', R4, 5' -ACGAAATTGGCCTCATCCGA-3'; F5, 5' -TTCGTACCGCTGCTGCTGCT3', R5, 5'-ACTCCTTCACCATCACCTCGTT-3'.

Immunoprecipitation of p $75 N T R$, transfection, and mass spectrometry. The PC12 cell line was obtained from American Type Culture Collection and grown in $\mathrm{F}-12 \mathrm{~K}$ medium supplemented with $15 \%$ horse serum and $2.5 \%$ fetal bovine serum in $5 \% \mathrm{CO}_{2}$. Cells were stimulated with NGF ( 100 $\mathrm{ng} / \mathrm{ml}$ ) and after $24 \mathrm{~h}$ were lysed in T-PER tissue protein extraction reagent (Pierce) in the presence of $1 \times$ Complete Mini protease inhibitor mixture (Roche). After centrifuging twice at $12,000 \times g$, the protein concentration was assessed by Coomassie Plus protein assay (Pierce). The $500 \mu \mathrm{g}$ of total protein in the supernatant was incubated with anti-p75NTR Covance antibody (catalog \#PRB-602C; $5 \mu \mathrm{g} / \mathrm{ml}$ ) to immunoprecipitate p75NTR from these cells. The efficiency of immunoprecipitation was verified by Coomassie stain of SDS-PAGE gels. A robust rabbit IgG band and a clear p75NTR band was visible along with a few contaminating bands. HEK293 cells (American Type Culture Collection) were grown in medium supplemented with $10 \%$ horse serum in 5\% $\mathrm{CO}_{2}$. The HEK293 cells were transfected with pEF6/V5-His mammalian expression vector (Invitrogen) containing full-length chicken p75NTR or control empty plasmid using Lipofectamine 2000 according to the manufacturer's protocol and subsequently were grown in the presence of NGF $(100 \mathrm{ng} / \mathrm{ml})$. Forty-eight hours after transfection, cells were lysed in the presence of protease and phosphatase inhibitors, and His-tagged chicken p75NTR was purified on metal affinity TALON columns (BD Biosciences) according to the manufacturer's protocol.

Protein samples in duplicate were separated on 12\% SDS-PAGE, gel bands representing p75NTR were cut, and in-gel trypsin digestion was performed (reduction with DTT; alkylation with iodoacetamide; reaction was stopped with formic acid). The primary and secondary peptides were analyzed using nano liquid chromatography-tandem mass spectrometry (LC/MS/MS) technique on a Micromass Q-Tof 2 and Finnigan LTQ by Proteomics Research Services. The $15 \mu \mathrm{l}$ of hydrolysate was processed on a $75 \mu \mathrm{m} \mathrm{C18} \mathrm{column} \mathrm{at} \mathrm{a} \mathrm{flow} \mathrm{rate} \mathrm{of} 200 \mathrm{nl} / \mathrm{min}$, and MS/MS data were processed using a local copy of MASCOT (Matrix Science) searching the human and rat IPI database as well as targeted database. Finally, the MASCOT search results were processed by Scaffold algorithm (Proteome Software). Parameters for LTQ data required a minimum of three peptides matching per protein with minimum prob- 
abilities of $95 \%$ at the protein level and $80 \%$ at the corresponding peptide level. QTOF data required a minimum of two peptides with the same minimum probability thresholds because of the superior mass accuracy of that instrument. Samples analyzed by mass spectrometry contained rat p75NTR protein (PC12 cells) and chicken p75NTR (transfected HEK293 cells) along with few other proteins, likely representing contaminants attributable to the antibody cross-reactivity and incomplete separation of proteins by SDS-PAGE. The sequence coverage for rat and chicken p75NTR by unique peptides was in the range of $20-30 \%$. Only peptides with conclusive fragmentation profiles and with superior quality for reconstruction of the amino acid sequence were taken into account. To identify phosphorylated amino acid residues, the samples were subjected to MS3 protocol in which product ions containing a loss of 80 or $98 \mathrm{Da}$ from the primary product ions are fragmented further. Several serines/ threonines were found to be phosphorylated within the intracellular domain of p75NTR (see Results).

In vitro protein kinase assay procedure. Recombinant active forms of protein kinase A (PKA), PKC $\alpha, \mathrm{PKC} \beta, \mathrm{PKC} \gamma, \mathrm{PKC} \delta, \mathrm{PKC} \zeta$, calcium/ calmodulin-dependent protein kinase II (CAMKII), CAMKIV, GSK $3 \alpha$, and casein kinase 2 kinases were obtained from Millipore, and recombinant active p38 $\beta$ MAPK (mitogen-activated protein kinase) was obtained from Roche. Five micrograms of wild-type chicken p75-ID (intracellular domain) were used per assay. $\left[\gamma^{-32} \mathrm{P}\right] \mathrm{ATP}$ was from PerkinElmer. The reaction conditions were as specified by the manufacturer for each kinase. All reactions were incubated for $20 \mathrm{~min}$ at $30^{\circ} \mathrm{C}$ in total volumes of 25-40 $\mu$ l. Histone protein (Sigma-Aldrich) was used as a positive control. To test the effect of inhibitors on PKC $\gamma$ activity, K252a at concentrations of 10 and $50 \mathrm{~nm}$ was added to the reaction buffer and Gö6976 was used at a concentration of $50 \mathrm{~nm}$. Each sample was mixed with SDS-PAGE sample buffer, boiled, and resolved by electrophoresis on a $15 \%$ SDS-PAGE polyacrylamide gel, and the gel was dried and exposed to $\mathrm{X}$-ray film.

${ }^{32} \mathrm{P}$ kinase in vitro assay: effects of inhibitors in cell lines. To directly test whether PKC inhibitors reduce p75NTR phosphorylation, we performed an in vitro phosphorylation assay. In brief, PC12 cells, NB2 cells and HEK293 cells were treated with or without PKC inhibitors (K252a or Gö6976 at $0.2 \mu \mathrm{M}$ in the tissue culture medium). One microcurie of ${ }^{32} \mathrm{P}$-labeled ATP was added to the medium, and then, after $1 \mathrm{~h}$, inhibitor was added and cells were incubated for an additional 2-3 h. Cells were incubated in the presence of $100 \mathrm{ng} / \mathrm{ml} \mathrm{NGF}$. After $4 \mathrm{~h}$ of incubation, cells were harvested, protein was extracted, and p75NTR was immunoprecipitated with Ig192 monoclonal antibody or other established p75NTR antibodies (Millipore Bioscience Research Reagents) for NB2 cells. Using recombinant protein G-agarose beads (Invitrogen), proteins were washed and subsequently resolved on $10 \%$ SDS gels. Gels were dried and exposed to x-ray films. Between two and four independent experiments were performed for each of the three cell lines.

In vitro coimmunoprecipitation. Recombinant purified p75NTR $(2 \mu \mathrm{g})$ and recombinant active $\mathrm{PKC} \gamma(2 \mu \mathrm{g}$; Calbiochem $)$ were incubated with anti-p75 polyclonal $\mathrm{Ab}(1 \mu \mathrm{g}$; Covance; catalog \#PRB-602C) in PBS, pH 7.4, for $30 \mathrm{~min}$ at room temperature in the presence of $1 \times$ Complete Mini protease inhibitor mixture (Roche). Subsequently, recombinant protein G-agarose was added for $10 \mathrm{~min}$, and samples were washed three times in $500 \mathrm{~mm} \mathrm{NaCl} / 10 \mathrm{~mm} \mathrm{Na}$-phosphate, $\mathrm{pH}$ 7.4, containing $0.1 \%$ Nonidet P-40, and final wash was performed in PBS. Control reactions included omission of anti-p75 Ab and omission of p75NTR protein in the reaction. After the washing step, SDS-PAGE sample buffer was added, and samples were boiled for $5 \mathrm{~min}$ and resolved on 12\% SDSPAGE gel. Proteins were transferred to nitrocellulose membranes in Tris/ glycine buffer containing 20\% methanol. Blots were probed with antiHis $\mathrm{Ab}$ (QIAGEN) and with alkaline phosphatase (AP)-labeled secondary Ab. Proteins were visualized with Western Blue stabilized AP substrate (Promega).

Quantification of cell death in the ION. Embryos at ages E13-E14 received intraocular injections of NGF alone (1 $\mu \mathrm{g}$ in PBS), NGF $(1 \mu \mathrm{g})$ plus Gö6976 ( $1 \mu \mathrm{l}$ of $250 \mu \mathrm{M}$ in DMSO), Gö6976 alone ( $1 \mu \mathrm{l}$ of $250 \mu \mathrm{M}$ in DMSO), K252a alone ( $1 \mu \mathrm{l}$ of $250 \mu \mathrm{m}$ in DMSO), or NGF ( $1 \mu \mathrm{g}$ in PBS) plus K252a ( $1 \mu \mathrm{l}$ of $250 \mu \mathrm{M}$ in DMSO), and were allowed to survive for $24 \mathrm{~h}$. The animals were killed at ages E14-E15 by decapitation, and heads were fixed by immersion in Methacarn's fixative. The brains were dissected, dehydrated in methanol, and embedded in paraffin as previously described (von Bartheld et al., 1996b; Janiga et al., 2000; von Bartheld and Johnson, 2001). The isthmic region of the brain containing the right and left IONs was serially sectioned in the transverse plane at $12 \mu \mathrm{m}$. Every fourth section was collected and stained with thionin, and pyknotic cells were counted according to Clarke and Oppenheim (1995). Approximately 30-90 pyknotic cells were counted for each ION in four independent experiments. The ipsilateral ION was used as an internal control. The results were calculated as a relative change observed in the contralateral ION (expressed as a percentage) compared with the control ipsilateral ION. Statistical significance was determined by unpaired two-tailed $t$ test.

\section{Results}

Cross-linking and immunoprecipitation reveals dynamics of neurotrophin binding to receptors during retrograde axonal transport

Receptors are crucial for the retrograde axonal transport of neurotrophins (Curtis et al., 1995; von Bartheld et al., 1996b; Butowt and von Bartheld, 2003), yet it is unknown whether receptors are required only for internalization, or if neurotrophins remain bound to their receptors during axonal transport (Sorkin and von Zastrow, 2002). To determine whether and which receptors bind neurotrophins during their retrograde axonal transport in vivo, we used cross-linking and immunoprecipitation with established antibodies against chicken $\mathrm{p} 75 \mathrm{NTR}$, trkB, trkC, or trkA. To control for possible "contamination" with anterogradely transported neurotrophins in retinal ganglion cell axons (von Bartheld et al., 1996a; Butowt and von Bartheld, 2005), neurotrophins were injected in the eye with and without monensin, which abolishes anterograde axonal transport, while leaving retrograde transport (along isthmo-optic axons) unaffected (von Bartheld et al., 1996b; Butowt and von Bartheld, 2001). Western blot analysis has shown that the p75NTR and trkB antibodies used here have approximately equal immunoprecipitation efficiencies (Herzog and von Bartheld, 1998). Since it can be assumed that crosslinking and immunoprecipitation efficiencies do not change between preparations from the chiasm and the ION for the same neurotrophin, our analysis should reveal any major changes in the ratios of receptor binding. The data are accordingly presented as percentages of total receptor binding, with the total binding to trkB, trkC, and p75NTR combined equal to $100 \%$ (Fig. 1A,B). There was no significant difference between the values with or without monensin for BDNF or NT-3 binding, and the data for the two conditions were therefore combined in the graphs (Fig. 1 $A, B$ ).

The cross-linking and immunoprecipitation experiments revealed that a substantial fraction $(\sim 40-50 \%)$ of neurotrophins was bound to receptors during transport. In the chiasm, $40-60 \%$ of (receptor-bound) BDNF and NT-3 bound to p75NTRs (Fig. 1A; supplemental Fig. $1 D$, available at www.jneurosci.org as supplemental material), but in the ION most of the BDNF (nearly $80 \%$ ) bound to trkB receptors. Thus, our immunoprecipitation experiments indicate that, during or immediately after retrograde transport, much of the BDNF translocated from p75NTRs (in the chiasm) to trkB (Fig. 1 A, BDNF) and trkC (supplemental Fig. $1 D, \mathrm{NT}-3$, available at www.jneurosci.org as supplemental material) on arrival at the neuronal cell bodies in the ION. NGF bound exclusively to the p75NTR during axonal transport to the ION and remained bound to this receptor (Fig. $1 B$ ), consistent with the fact that trkA is not expressed in the ION (see below).

The percentages for immunoprecipitation with the crosslinkers EDC or DSS were very similar, with DSS showing a slightly 

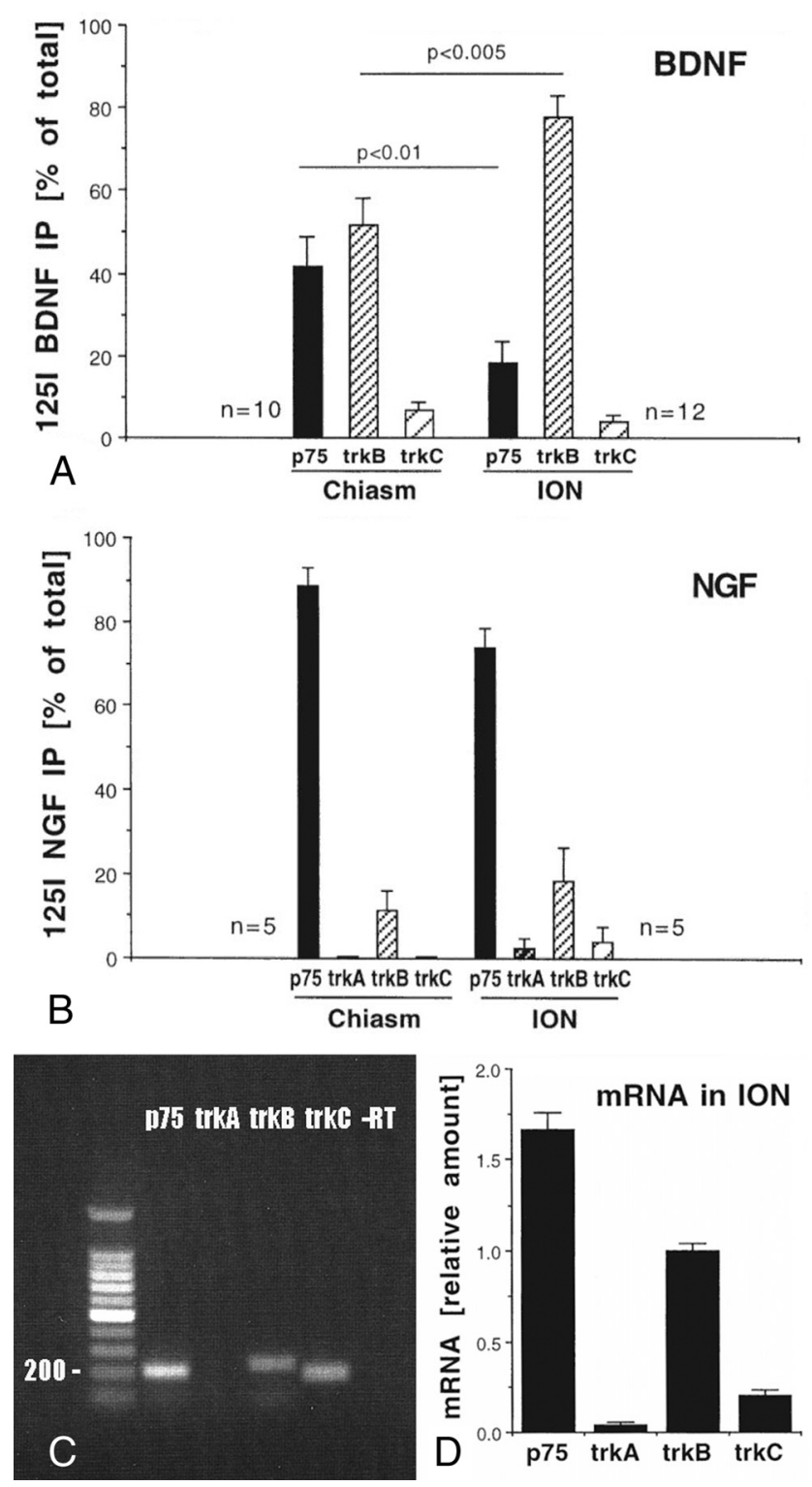

Figure 1. $\boldsymbol{A}-\boldsymbol{D}$, Receptor binding of retrogradely transported neurotrophins and expression of neurotrophin receptors in the ION of 14- to 16-d-old chick embryos. $A$, Immunoprecipitation of radiolabeled BDNF cross-linked to its receptors reveals a significant shift en route, from p75NTR (p75) in the chiasm to trkB on arrival in the ION. Data are expressed as a percentage of BDNF relative to all receptor-bound BDNF. $\boldsymbol{B}$, NGF binds nearly exclusively to p75NTR (p75), consistent with the absence of trkA expression by the ION (see C). C, Expression of trks and p75NTRs (p75) by the I0N, as measured by qualitative RT-PCR. Note the lack of trkA expression and the relative abundance of p75NTR. D, Quantitative RT-PCR of trk and p75NTR (p75) expression in the ION, confirming virtual lack of trkA expression. Error bars indicate SEM.

higher ratio for the trk receptor, and EDC showing a slightly higher ratio for the p75NTR (supplemental Fig. $1 B, C$, available at www.jneurosci.org as supplemental material). This is in agreement with the known higher efficiencies of these cross-linkers for trks (DSS) and for p75NTR (EDC), respectively (Escandón et al., 1993). A series of control experiments was performed to verify that neurotrophins do not significantly dissociate from their receptors and bind to other, previously unoccupied, receptors that become available in the lysis step. When BDNF or NT-3 was added to the lysed chiasm or ION, the ratios of binding were significantly different (supplemental Fig. $1 F$, available at www. jneurosci.org as supplemental material). Notably, when NT-3 was added to the chiasm or ION, it bound much more to trkB than it did when it was introduced into the ION axons by intraocular injection, internalization, and retrograde transport (supplemental Fig. 1D,F, available at www.jneurosci.org as supplemental material). When the cross-linking step was omitted, most neurotrophin binding to p75NTR was lost, whereas binding to trk receptors was maintained (supplemental Fig. $1 E$, available at www.jneurosci.org as supplemental material). This is consistent with the notion that p75NTRs are "fast" receptors that bind ligands with a fast rate of dissociation, whereas trk receptors may bind ligands with higher affinity and release the neurotrophins slowly (Barker and Murphy, 1992; Bothwell, 1995).

Thus, use of an advantageous in vivo model system for retrograde axonal transport of neurotrophins reveals that (1) a major fraction of neurotrophins (at least $30-40 \%$ of the total) bound to receptors during the retrograde journey; (2) that among the fraction of BDNF that was receptor-bound, most bound p75NTR in the axon (chiasm), but bound trkB in the cell body (ION); (3) thus, BDNF appears to switch from p75NTR to trkB during or after retrograde axonal transport; (4) we furthermore conclude that at least some of the p75NTR and trkB molecules likely reside within the same vesicle or endosome-unless distinct types of endosomes fuse their membranes en route between the chiasm and cell body. Another possibility, that the BDNF bound to p75NTR is more rapidly degraded in the ION than BDNF bound to $\operatorname{trkB}$, is ruled out by additional experiments showing the opposite: that ligands bound to $\mathrm{p} 75 \mathrm{NTR}$ are degraded with a delay (see below). Since p75NTR and trk receptors do not seem to directly interact to form high-affinity binding sites (Wehrman et al., 2007; Gong et al., 2008), our findings support the notion that enhanced effects of neurotrophins in the presence of both p75NTR and trk receptors arise from increased availability of ligands, including the gradual transfer of ligands from p75NTR to trk receptors within signaling endosomes during axonal transport.

\section{ION neurons express p75NTR, trkB, and trkC, but no trkA}

Expression of neurotrophin receptors in the ION was previously examined by in situ hybridization (von Bartheld et al., 1991, 1996b; Garner et al., 1996; Strohmaier et al., 1996). Although expression of p75NTR and trkB was reported, no trkC or trkA mRNA was detected in the ION. Our present immunoprecipitation experiments revealed small, but detectable amounts of NT-3 that were cross-linked to trkC receptors in the ION and in ION nerve fibers within the chiasm (Fig. $1 A$; supplemental Fig. $1 D$, available at www.jneurosci.org as supplemental material). This suggests that the developing chick ION neurons express trkC receptors. Therefore, we reexamined receptor expression in the ION by qualitative and quantitative real-time reverse transcription (RT)-PCR. IONs dissected from E14-E15 chick embryos expressed, in addition to the expected p75NTR and trkB (Fig. $1 C, D)$, also moderate, yet clearly visible levels of trkC, but we failed to detect trkA expression (Fig. 1C,D). Comparison of levels of cDNA for these receptors in the same ION samples from E15 chick embryos showed that the relative ratio of $\mathrm{p} 75 / \operatorname{trkB} / \operatorname{trkC}$ expression may be estimated as 1.7:1:0.2 (Fig. 1D). Most likely, trkC expression in the ION is below levels that can be easily detected by in situ hybridization. The ION neurons do not express NGF, BDNF, or NT-3, at least not during the embryonic period E12-E17 (data not shown); however, these neurotrophins are expressed in the retina (Hallböök et al., 1996). Thus, the relative levels of neurotrophin receptor expression closely match the receptor binding capacity in the ION, as shown by BDNF and NT-3 cross-linking and immunoprecipitation after addition of 

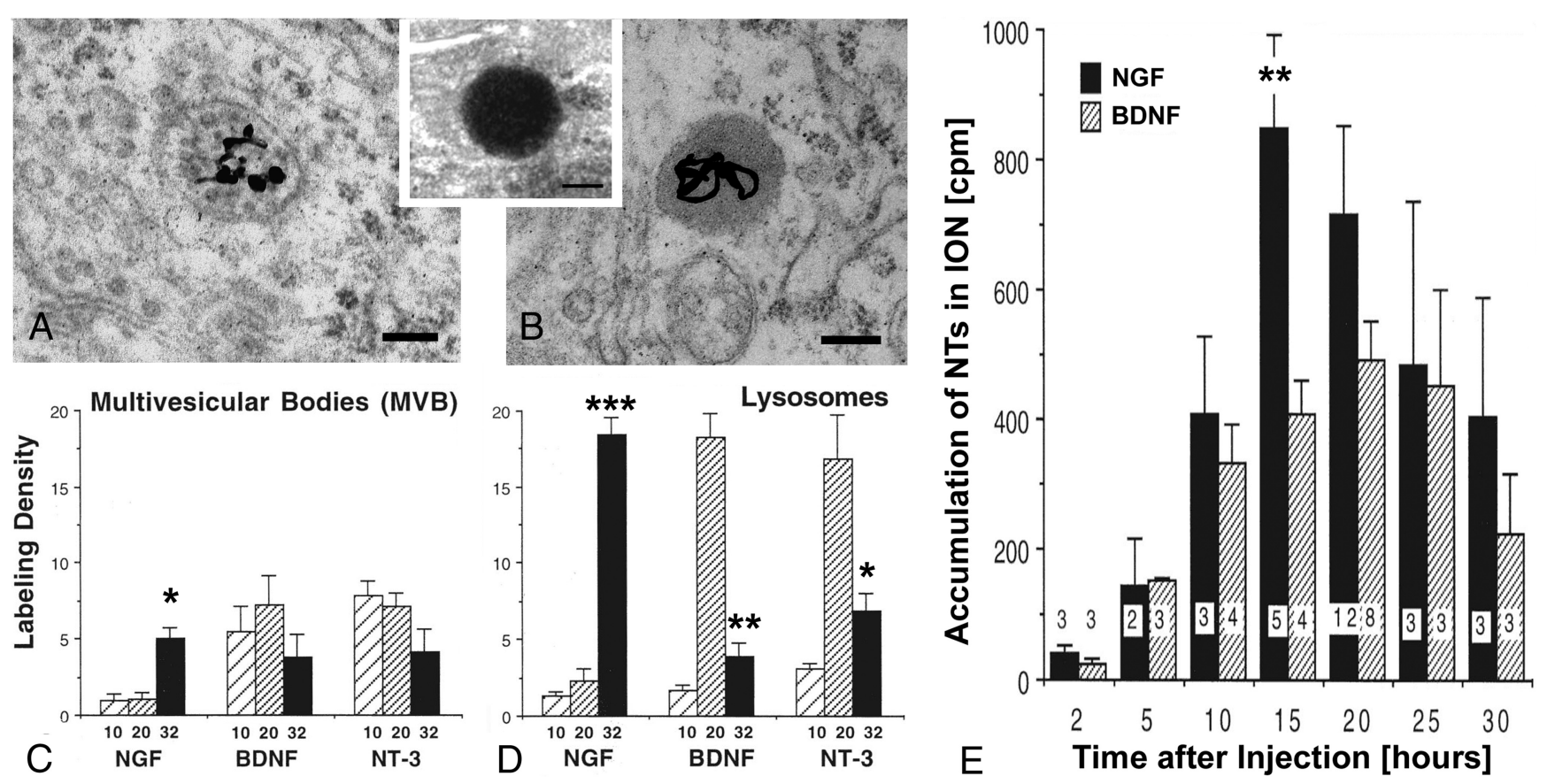

Figure 2. $A-E$, Accumulation of retrogradely transported neurotrophins in MVBs and lysosomes in the $I O N$ of $E 15$ chick embryos $(\boldsymbol{A}-\boldsymbol{D})$ and comparison of NGF and BDNF arrival and accumulation in the ION $(\boldsymbol{E}) . \boldsymbol{A}$, Silver grain indicative of retrogradely transported neurotrophin in an MVB within the ION. $\boldsymbol{B}$, Silver grain indicative of retrogradely transported neurotrophin in a lysosome within the ION. Scale bar: $\boldsymbol{A}, \boldsymbol{B}, 200 \mathrm{~nm}$. Inset, Lysosome showing dark precipitate after enzyme histochemistry for acid phosphatase. Scale bar, $200 \mathrm{~nm}$. C, Quantification of accumulation of NGF, BDNF, and NT-3 in MVBs at 10, 20, and $32 \mathrm{~h}$ after intraocular injection by autoradiography. Data are based on two to three independent experiments. Error bars indicate SEM. Statistically significant differences in $\boldsymbol{C}-\boldsymbol{E}$ (unpaired Student's $\mathrm{s}$ test) between adjacent bars are indicated by asterisks ( ${ }^{*} p<0.05 ;{ }^{* *} p<0.025 ;{ }^{* * *} p<0.01$ ). $\boldsymbol{D}$, Quantification of accumulation of NGF, BDNF, and NT-3 in lysosomes at 10,20, and $32 \mathrm{~h}$ after intraocular injection. Note the consistent difference between NGF and the other two neurotrophins (BDNF and NT-3) in the kinetics of both MVB and lysosome transition. E, Accumulation of radiolabeled NGF and BDNF in the ION after intraocular injection. Note that both neurotrophins (NGF and BDNF) arrive in the ION at 5-10 h, and their accumulations peak at $15-20$ h. More NGF accumulates at $15-20 \mathrm{~h}$, consistent with a delayed degradation on arrival compared with BDNF. Error bars indicate SEM. The number $(n)$ of independent experiments is indicated on bars. Values of $p$ are indicated by an asterisk $\left(^{*}\right)$ only when they reach statistical significance.

exogenous radiolabeled neurotrophins to lysed IONs (supplemental Fig. $1 F$, available at www.jneurosci.org as supplemental material). Together, we conclude that the data on neurotrophin receptor expression in the chick ION are consistent with the results from our receptor-binding data.

\section{Ultrastructural distribution of target-derived NGF, BDNF, NT-3, and NT-4 in ION neurons}

Our immunoprecipitation data show that neurotrophins can arrive in the ION bound to either p75NTR or trk receptors. NGF, apparently acting via p75NTR, increases cell death in the developing ION (von Bartheld et al., 1994) and also in other systems (for review, see Roux and Barker, 2002), whereas binding of BDNF to trkB and NT-3 to trkC enhances ION neuron survival (von Bartheld et al., 1994; Primi and Clarke, 1996; Janiga et al., 2000). We asked whether the two distinct signaling pathways may be reflected by distinct accumulation of different neurotrophins in different organelles at the ultrastructural level. On the basis of the apparent expression of $\mathrm{p} 75 \mathrm{NTR}$, trkA, trkB, and trkC receptors in the ION, one would expect that ION terminals may internalize NGF (via p75NTR), BDNF (via p75NTR and/or trkB), NT-3 (via p75NTR, trkB and/or trkC), and NT-4 (via p75NTR and/or trkB). Thus, binding to different receptors may determine intracellular trafficking pathways. To examine whether different members of the neurotrophin family accumulate in the same or in different organelles within ION cell bodies after retrograde axonal transport, radiolabeled neurotrophins were injected into the vitreous body of the eye in E15-E16 embryos. After three different time points $(10,20$, and $32 \mathrm{~h})$, IONs were processed to quantify the distribution of autoradiographic silver grains at the ultrastructural level (Fig. 2A,B). Control embryos injected with free iodide did not accumulate silver grains in the ION (data not shown). These control experiments also indicated that background labeling was very low in our experimental system.

Qualitative analysis of the distribution of silver grains in the ION at 10,20 , and $32 \mathrm{~h}$ revealed no obvious differences between different neurotrophins. Quantitative analyses at $20 \mathrm{~h}$ showed that all four neurotrophins accumulated with substantial labeling densities (LD > 2.5) in organelles of the endocytic and degradative pathways such as clear vesicles, light and dense endosomes, lysosomes, as well as MVBs (Fig. 2C,D; supplemental Table 1, available at www.jneurosci.org as supplemental material). Examples of silver grains located over these types of organelles in ION cell bodies are shown in Figure 2, $A$ and $B$. The lysosomal nature of dense endosomes was verified by acid phosphatase enzyme histochemistry (Fig. 2, inset). There was no preferential accumulation of grains (labeling densities were $<2.5$ ) over other organelles, such as nuclei (including nuclear membrane), endoplasmic reticulum, Golgi apparatus (including Golgi-associated vesicles), mitochondria, or plasma membrane (supplemental Table 1, available at www.jneurosci.org as supplemental material). We next quantified the time course of organelle accumulation and transition for the different neurotrophins.

Time course and differences between NGF, BDNF, NT-3, and NT-4 accumulation at 10, 20, and $32 \mathrm{~h}$

Previous studies in other systems have shown that the kinetics (timing/duration) of signaling pathway activation can be crucial for important cellular functions [e.g., the EGF (epidermal growth factor)/NGF activation of MAP kinase] (Traverse et al., 1992; 
Marshall, 1995). Therefore, we analyzed the precise timing of organelle accumulation of both p75NTR-bound and primarily trk-bound neurotrophins in the ION. The time course of NGF, BDNF, NT-3, and NT-4 accumulation in the ION after retrograde transport showed remarkable differences between these neurotrophic factors. Neurotrophins that bind trk receptors (BDNF, NT-3, and NT-4) accumulated significantly faster $(p<$ 0.05 ) in the lysosomal/dense endosomal compartment than the neurotrophin NGF that binds exclusively to p75NTR in this system (Fig. $2 C, D$ ). At the $20 \mathrm{~h}$ time point, BDNF, NT-3, and NT-4 had reached their maximum of labeling in dense endosomes, lysosomes, and MVBs (Fig. 2C,D; supplemental Table 1, available at www.jneurosci.org as supplemental material), and their labeling was decreased in light endosomes and vesicles (supplemental Table 1, available at www.jneurosci.org as supplemental material). Such changes were not yet visible at the $20 \mathrm{~h}$ time point for NGF and appear for this neurotrophin only $32 \mathrm{~h}$ after injection (Fig. 2C,D; supplemental Table 1, available at www.jneurosci.org as supplemental material). At the $20 \mathrm{~h}$ time point, labeling of the lysosomal/endosomal compartment and of the MVBs was significantly, approximately five to seven times lower for NGF than the other neurotrophins. The opposite pattern was apparent for the lysosomal/endosomal compartment $32 \mathrm{~h}$ after injection. LDs in MVBs reach similar values for all neurotrophins $32 \mathrm{~h}$ after injection. Together, these data indicate that the exclusively p75NTRbinding NGF has much delayed kinetics of organelle transition and presumptive degradation compared with the other, primarily trk-bound neurotrophins. Kinetics of neurotrophin trafficking and sorting thus appears to reflect survival- versus death-signaling in this in vivo model system.

\section{Comparable speed of retrograde axonal transport of neurotrophins into ION cell bodies}

The differences between NGF and other neurotrophins in kinetics of transition through different organelles of the endocytic compartment may be caused either by different sorting kinetics of p75NTR-bound NGF compared with trk-bound BDNF and NT-3, or by delayed arrival at the cell body because of internalization delays (Ure and Campenot, 1997; Weible et al., 2001; Bronfman et al., 2003) or slower speed of retrograde transport of NGF along the ION axons. Indeed, a fast retrograde apoptotic signal (possibly NGF-bound p75NTR) has been postulated to exist in the ION axons (Clarke et al., 1998). To rule out the latter possibilities, we compared the speed of retrograde axonal transport of NGF and BDNF from the eye into the ION. Accumulation of radioactivity (cpm) was measured in serial vibratome sections through the ION at seven time points $(2-30 \mathrm{~h})$ after intraocular injections. When the onset of accumulation of radioactivity in the ION was plotted as a function of time after injection, the peaks of NGF and BDNF overlapped with no significant differences for the arrival of the two neurotrophins (2-10 h; $p>0.05)$ (Fig. 2E). Therefore, the time interval after which NGF and BDNF arrived in ION neurons was similar for these neurotrophins. In fact, at later time points (15-20 h), NGF accumulation peaked before that of BDNF, possibly because BDNF was already being degraded, whereas NGF degradation was relatively delayed (Fig. $2 E$ ) (see below). Nevertheless, NGF and BDNF appear to have a similar velocity of axonal retrograde transport into ION cell bodies, as was also shown for BDNF and NGF transport in a different system (Hibbert et al., 2006). We conclude that differences in the kinetics of transition through organelles of the endocytic and degradative pathway cannot be explained by differences in axonal speed between NGF and other neurotrophins, but appear to be caused by differences in sorting mechanisms at the level of the cell body. This is consistent with previous suggestions of two distinct degradation kinetics for NGF in cells that contain both trkA and p75NTR (Ure and Campenot, 1997).

\section{Treatment with K252a in the target directs NGF into a rapid sequestering and degradation pathway after retrograde axonal transport}

Tyrosine kinase activity has been implicated in the sorting of internalized receptor-ligand complexes (Felder et al., 1990; Bos et al., 1993; Opresko et al., 1995). A relatively specific tyrosine kinase inhibitor, K252a, shifted NT-3 and BDNF into a lysosomal pathway in retinal ganglion cells of chick embryos (Butowt and von Bartheld, 2001). K252a does not inhibit retrograde axonal transport of BDNF to the ION after intraocular injection (von Bartheld et al., 1996b; Butowt and von Bartheld, 2001). This indicates that tyrosine kinase inhibition does not alter the speed and/or time of neurotrophin arrival in the ION. However, it has not been examined at the ultrastructural level whether K252a has any effects on the sorting of retrogradely transported neurotrophins. Here, we examined whether K252a altered the distribution and sorting of radiolabeled neurotrophins in the ION after retrograde transport in this in vivo system.

Coinjection of $\mathrm{K} 252 \mathrm{a}$ ( $1 \mu \mathrm{l}$ of $0.25 \mathrm{~mm}$ per eye) with radiolabeled neurotrophins significantly altered the pattern of accumulation of NGF in the ION, without any significant effect on accumulation of BDNF and NT-3 (Fig. 3; supplemental Table 2, available at www.jneurosci.org as supplemental material). At the $20 \mathrm{~h}$ time point, the distribution of ${ }^{125} \mathrm{I}-\mathrm{NGF}$ changed substantially in the presence of $\mathrm{K} 252 \mathrm{a}$, and now resembled the normal distribution of the other (trk-binding) neurotrophins. NGF normally did not accumulate in the MVB at $20 \mathrm{~h}$ (LD 1.0), but K252a changed this significantly $(p<0.01)$ to an LD of 11 . NGF normally accumulated in lysosomes at $20 \mathrm{~h}$ with a LD of $\sim 2.0$, but with K252a this changed significantly to an LD of 14 ( $p<$ $0.01)$. NGF normally accumulated at $32 \mathrm{~h}$ in lysosomes with an LD of $\sim 18$, but with K252a, this LD was significantly $(p<0.05)$ changed to a LD of 4 (K252a). Thus, K252a significantly shifted the presumptive kinetics of NGF degradation in organelles of the degradative pathway such as dense endosomes/lysosomes and multivesicular bodies from the $20 \mathrm{~h}$ to the $32 \mathrm{~h}$ time point (supplemental Table 2, available at www.jneurosci.org as supplemental material). Importantly, the distribution of trkB-binding BDNF (Fig. 3; supplemental Table 2, available at www.jneurosci. org as supplemental material) and trkC-binding NT-3 (data not shown) was not significantly altered by K252a treatment. Other patterns of distribution were also not significantly altered. These data suggest that tyrosine kinase activity of trkB or trkC does not regulate distribution or sorting of retrogradely transported neurotrophins into the ION. The results are unexpected with regard to NGF, since NGF binds in this system exclusively to the p75NTR, which has no tyrosine kinase enzymatic activity (Roux and Barker, 2002). The altered pattern of NGF distribution with K252a treatment indicates that this compound may inhibit other kinases than trks in this system, and these additional effects of K252a appear to lead to changes in NGF sorting via p75NTR.

\section{Cloning of cDNA for chicken p75NTR receptor}

The chicken p75NTR ("NGF receptor") was originally cloned by Large et al. (1989) and Heuer et al. (1990); however, the cDNA sequence was never made available in public databases such as GenBank. To detect possible errors before generation of expression constructs, and to make the sequence available in GenBank, 


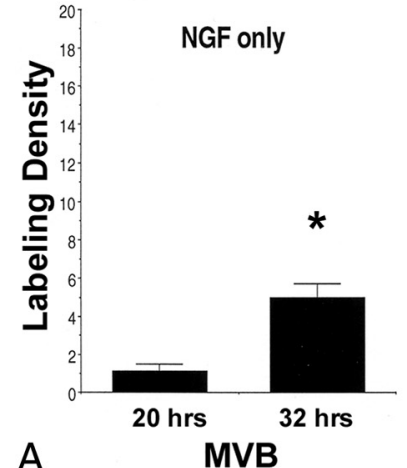

A
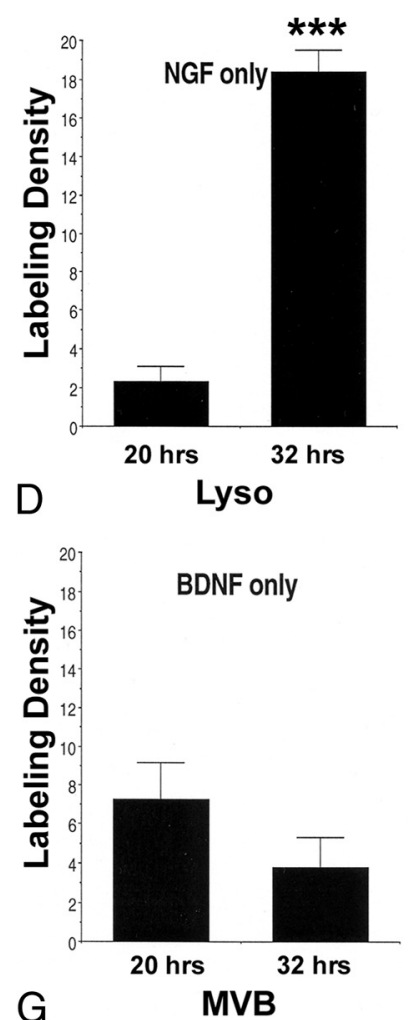

G

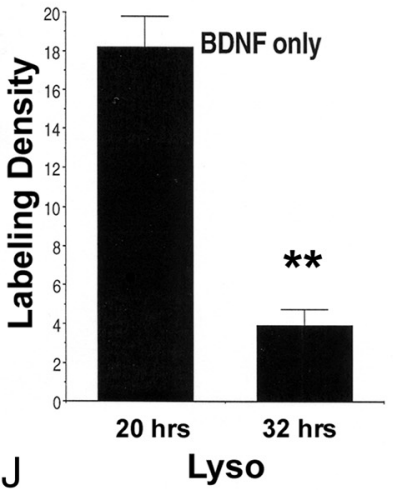

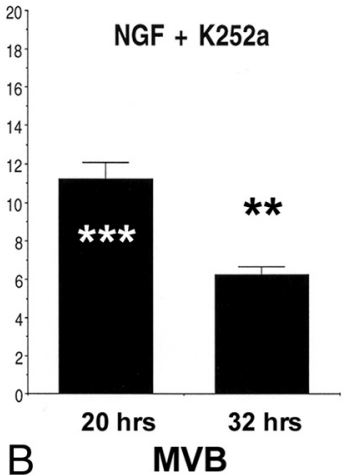
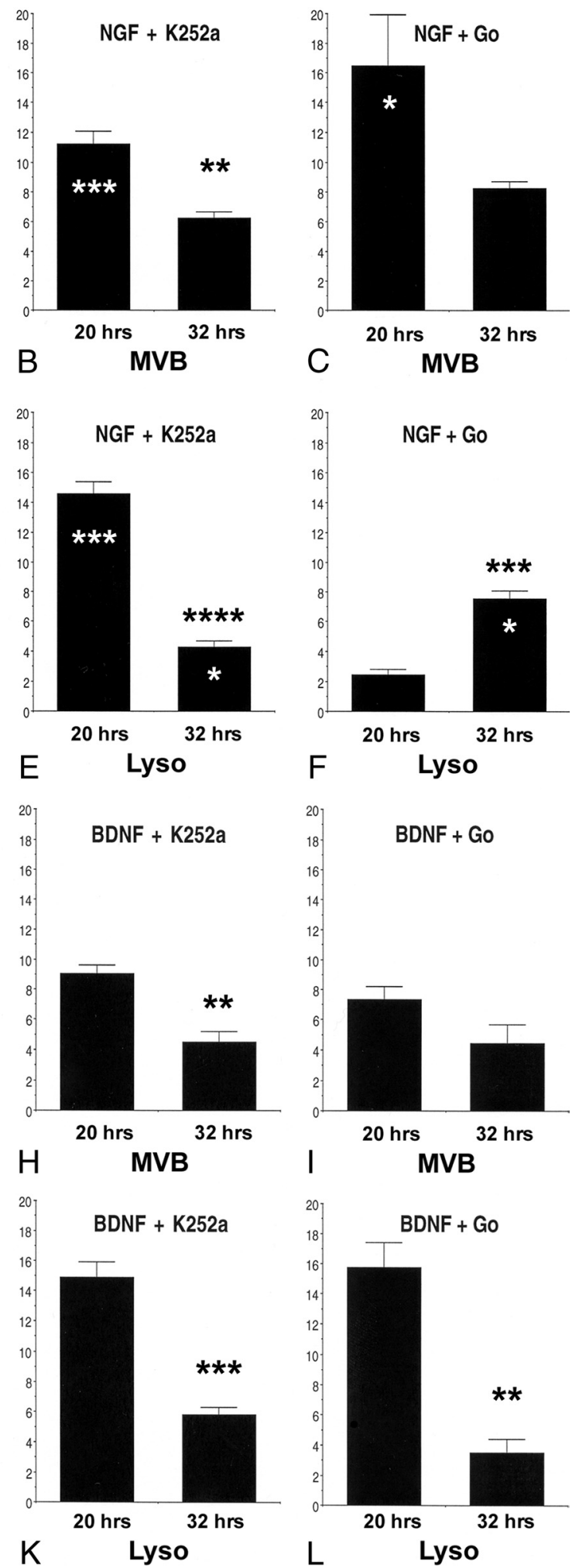

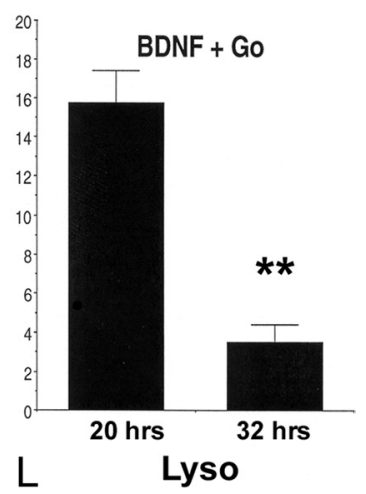

we cloned this gene using PCR strategy. The sequence is available under accession number EU282004. This sequence differs in $12 \mathrm{nt}$ from the sequence reported by Large et al. (1989). There is one amino acid difference at the protein level (at position 304, there is $\mathrm{H}$ instead of Q). Other changes in nucleotides are neutral for amino acid composition.

Effect of K252a on sorting of NGF may be mediated by inhibiting phosphorylation of p75NTR through conventional PKCs

K252a specifically inhibits trk tyrosine kinase activity in a concentration range of 1-10 nм (Koizumi et al., 1988; Berg et al., 1992). However, doses of 20-50 nM may also effectively inhibit PKA, PKC, and other classes of kinases (Kase et al., 1987; Rüegg and Burgess, 1989). The p75NTR can be robustly phosphorylated on different serine/threonine residues, but the in vivo functions of these posttranslational modifications are not known (Grob et al., 1985; Taniuchi et al., 1986; Roux and Barker, 2002; Higuchi et al., 2003). We hypothesized that the effect of $\mathrm{K} 252 \mathrm{a}$ on NGF sorting in ION neurons may be attributable to the inhibition of phosphorylation of the intracellular domain of p75NTR by yet-unknown serine/threonine kinase(s). To test this hypothesis, we expressed and purified the recombinant His-tagged intracellular domain (ID) of human p75NTR in the Escherichia coli system. Subsequently, we used the p75-ID for in vitro kinase assays in combination with $\left[\gamma_{-}{ }^{32} \mathrm{P}\right]$ ATP and with several active purified kinases. Among several kinases tested, the conventional PKC $\gamma$, atypical PKC $\zeta$, CAMKII, and $\mathrm{p} 38 \beta$ showed strong phosphorylation of p75-ID (Fig. 4A). $\mathrm{PKA}, \mathrm{PKC} \delta, \mathrm{PKC} \varepsilon$, casein kinase 2, and GSK3 $\alpha$ showed no or weak phosphorylation of recombinant human p75-ID. Fifty nanomolar K252a inhibited phosphorylation of p75-ID by conventional PKC $\gamma$, but not by $\mathrm{PKC} \zeta$, p38 $\beta$ (Fig. $4 B, C$ ), or CAMKII (data not shown). Thus, conventional PKC may potentially phosphorylate $\mathrm{p} 75 \mathrm{NTR}$, and inhibition of its activity by K252a may lead to changes in sorting of

Figure 3. $A-L$, Comparison of accumulation and transition kinetics in MVBs and lysosomes (Lyso) of the E15 ION between NGF $(\boldsymbol{A}-\boldsymbol{F})$ and $\mathrm{BDNF}(\mathbf{G}-\boldsymbol{L})$ at 20 and $32 \mathrm{~h}$ after intraocular injection of neurotrophin only, or neurotrophin plus kinase inhibitors K252a or Gö6976 (Go). Data were obtained in two to three independent experiments with $\sim 150$ silver grains scored for each condition to determine labeling densities. Error bars indicate SEM. Statistical significance $(t$ test $)$ of changes within panels is indicated by black asterisks above error bars. We indicate statistically significant differences compared with the neurotrophin-only condition by white asterisks within the black bars, using Bonferroni's corrections for multiple comparisons. Note that NGF kinetics are significantly reversed by K252a and/or Gö6976 coinjection for MVBs and lysosomes, but the same inhibitors have no effect on BDNF kinetics of organelle transition. NGF normally did not accumulate in the MVB at $20 \mathrm{~h}$ (LD 1.0), but when coinjected with either K252a or Gö6976, NGF accumulated significantly $(p<0.01$ and $p<0.05$ ) with LDs of $11-16$. NGF normally accumulated in

$\leftarrow$

lysosomes at $20 \mathrm{~h}$ with a LD of $\sim 2.0$, but K252a changed this significantly to an LD of 14 ( $p<0.01$ ). NGF normally accumulated at $32 \mathrm{~h}$ in lysosomes with an $L D$ of $\sim 18$, but with either K252a or Gö6976, this accumulation was significantly ( $p<$ 0.05 ) reduced to LDs of 4 (K252a) and 7 (Gö6976). Statistically significant differences are indicated by asterisks $\left({ }^{*} p<0.05\right.$; $\left.{ }^{* *} p<0.025 ;{ }^{* * *} p<0.01{ }^{* * * *} p<0.005\right)$. 


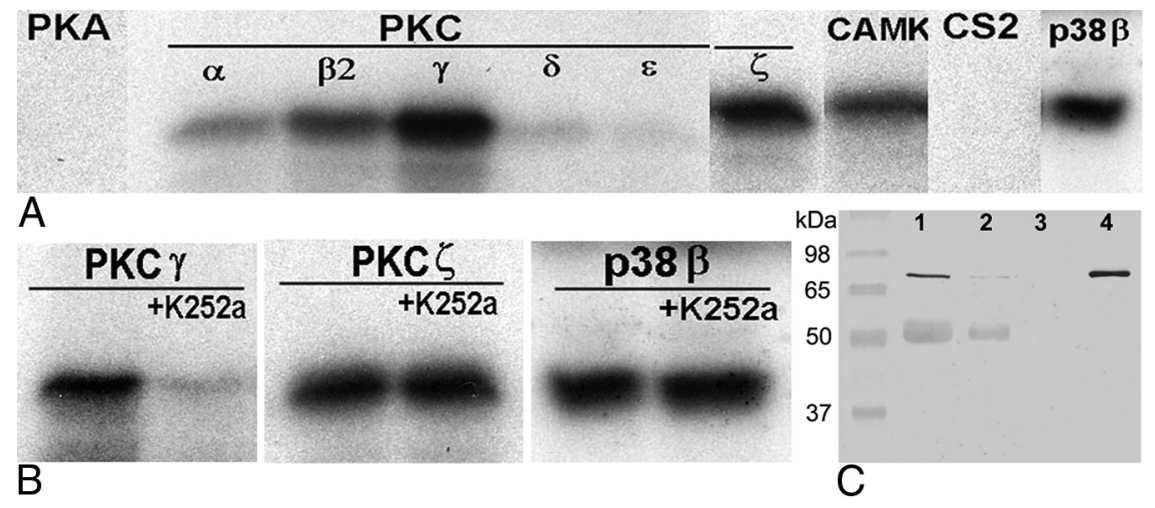

Figure 4. A-C, Conventional protein kinase C isoforms (PKC $\alpha,-\beta,-\gamma)$ effectively phosphorylate p75NTR, and this phosphorylation is abolished by the kinase inhibitor K252a. A, Human p75NTR is phosphorylated in vitro by several kinases, notably by conventional and atypical PKC, CAMKII, and mitogen-activated protein kinase $(p 38 \beta)$, but not by PKA, PKC $\delta$, PKC $\varepsilon$, or CSII (casein kinase II). B, K252a (50 nm) inhibits phosphorylation of p75NTR by PKC $\gamma$, but not by PKC $\zeta$ or p38 $\beta$. C, Evidence for direct interaction in vitro between purified p75NTR and purified PKC $\gamma$. Recombinant His-tagged PKC $\gamma$ $(\sim 80 \mathrm{kDa})$ is coimmunoprecipitated with the intracellular domain of p75NTR (p75-ID). Detection and visualization was performed with anti-His antibody and alkaline phosphatase-labeled secondary antibody. Lane 1, In the presence of all reaction components (purified PKC $\gamma$, purified p75-ID, and anti-p75 antibody), an intense PKC $\gamma$ band is visible $(\sim 80 \mathrm{kDa})$. Lane 2, When p75-ID is omitted, PKC $\gamma$ band is barely detectable. Lane 3, Control reaction without anti-p75 antibody. PKC $\gamma$ band is not present. Lane 4, Standard band of $200 \mathrm{ng}$ of PKC $\gamma(\sim 80 \mathrm{kDa})$.

NGF-p75NTR complexes in the ION after retrograde axonal transport.

To identify potential phosphorylation sites for conventional PKC within the intracellular domain of human p75NTR, we analyzed the p75-ID sequence using NetPhos 2.0 software. NetPhos 2.0 predicted that eight serines and two threonines have a high $(>83 \%)$ probability of being phosphorylated. On the basis of NetPhos results, we constructed and purified several mutants (m-1, m-2, m-3, m-4, and m-5) of His-tagged p75-ID, with serine/threonine substitutions for alanine, and tested them in kinase assays in vitro (see Materials and Methods). Mutant 1 ( $\mathrm{m}-1$, serine 277 and threonine 358 mutated to alanine) and 4 ( $\mathrm{m}-4$, only serine 277 mutated to alanine) showed significantly reduced phosphorylation by $\mathrm{PKC} \gamma$, whereas mutants 2 and 3 were phosphorylated similarly to wild-type p75-ID (Fig. 5A,B). Mutant 5 (with threonine 358 mutated to alanine) was also phosphorylated, similar to wild type p75-ID (data not shown). We conclude that serine 277 in the juxtamembrane region of p75-ID is the likely target for phosphorylation by conventional PKC in the ION (Fig. 5C), and this may be a regulatory step for sorting of p75NTR-ligand complexes. Serine 277 in human p75NTR is homologous to serine 266 in chicken p75NTR and the amino acid sequences adjacent to this serine are identical in both mammalian and chicken p75NTR (KRWNSCKQNK).

\section{Inhibition of conventional PKC directs p75NTR-bound NGF into a rapid degradation pathway in the ION, similar to treatment with $\mathrm{K} 252 \mathrm{a}$}

When K252a is used in concentrations $>20-50 \mathrm{nM}$, it is a relatively broad-spectrum kinase inhibitor (Rüegg and Burgess, 1989). Therefore, we tested the effects of the PKC inhibitor, Gö6976, on neurotrophin sorting in our model system. Gö6976 inhibits the conventional PKC isoforms and it was used previously in vivo (Sivasankaran et al., 2004). First, we tested Gö6976 $(50 \mathrm{nM})$ in a kinase in vitro assay and concluded that, similar to K252a, this inhibitor also decreased phosphorylation of p75-ID (data not shown). Subsequently, we coinjected radiolabeled NGF or BDNF $(4 \mu \mathrm{l})$ in the eye with Gö6976 $(1 \mu \mathrm{l}$ at $250 \mu \mathrm{M})$ and examined the ultrastructural distribution of NGF and BDNF after 20 and $32 \mathrm{~h}$ in ION cell bodies. Coinjection of Gö6976 significantly $(p<0.05)$ increased accumulation of NGF in multivesicular bodies at the $20 \mathrm{~h}$ time point (Fig. 3C), nearly identical to K252a (Fig. 3B), and substantially $(p<0.05)$ reduced the accumulation in lysosomes at $32 \mathrm{~h}$ (Fig. $3 D, F$ ), although not as dramatic as K252a (Fig. 3E), and with no significant effect on the LD in lysosomes at $20 \mathrm{~h}$ (Fig. 3D-F). Labeling of other organelles remained similar to the distribution of NGF injected without inhibitor (supplemental Tables 1, 2, available at www.jneurosci.org as supplemental material). Identical with K252a treatment, the Gö6976 treatment showed no significant effect on the distribution of BDNF in the ION (Fig. $3 I, L)$. As a control, we coinjected radiolabeled tetanus toxin (TeT) with Gö6976 in the same experimental condition. The distribution of TeT within multivesicular bodies was not altered by treatment with the inhibitor (data not shown). However, Gö6976 may also have effects on non-PKC kinases (Mok and Campenot, 2007). Therefore, we coinjected NGF with calphostin C, a relatively specific inhibitor of PKC enzymes with minimal effects on tyrosine kinases or other threonine/serine kinases (Lazarovici et al., 1998). However, calphostin $\mathrm{C}$ significantly reduced retrograde axonal transport of neurotrophins (data not shown), which makes this inhibitor unsuitable for testing intracellular sorting after retrograde axonal transport. Since we cannot exclude an unlikely, but theoretically possible indirect effect of the tested kinase inhibitors on trkB or trkC phosphorylation and a downstream effect on p75NTR (even in the absence of trkA, which is not expressed in the ION), we tested another kinase inhibitor, genistein, which is a relatively specific inhibitor for tyrosine kinases but has minimal effects on PKCs (Jinsi-Parimoo and Deth, 2000). As shown in the supplemental Table 2 (available at www.jneurosci.org as supplemental material), genistein did not alter the delayed accumulation of NGF in MVBs and lysosomes. Since genistein strongly inhibits tyrosine kinases, any direct or indirect effect mediated through trkB or trkC would have been apparent in this experiment. Therefore, effects of K252a or Gö6976 on p75NTR via changes of trkB or trkC phosphorylation appear highly unlikely. Together, our data indicate that inhibition of conventional PKC alters the sorting pathway of p75NTRNGF complexes after retrograde axonal transport into the ION, shifting its distribution into a rapid sequestration/degradation pathway. The mechanism of this process likely involves changes of the phosphorylation status of the p75NTR.

\section{Effects of kinase inhibitors on phosphorylation of p75NTR in cell lines}

To determine whether the PKC inhibitors K252a or Gö6976 reduce the phosphorylation of p75NTR in whole cells in vitro, we examined the effects of these inhibitors at $0.2 \mathrm{mM}$ on PC12, NB2 cells, and HEK293 cells by using a ${ }^{32} \mathrm{P}$ phosphorylation assay. P75NTR was immunoprecipitated before gel loading. Although p75NTR phosphorylation was clearly visible (supplemental Fig. 2, available at www.jneurosci.org as sup- 
plemental material), PKC inhibitors reduced the density of the p75NTR band only minutely and not consistently when compared with controls (no inhibitors). This may be attributable to the fact that p75NTR can be phosphorylated at multiple sites and by multiple kinases, not only the site targeted by PKC (Grob et al., 1985; Taniuchi et al., 1986). The fraction of p75NTR that is phosphorylated by PKC may be very small, and when only a small fraction of potential phosphorylation sites are inhibited, it is difficult to document significant changes in total phosphorylation status. Furthermore, as we found out later (see below), PKC seems to act primarily (if not exclusively) on axonally transported p75NTR, and this effect therefore would not be visible in cell lines.

\section{Difference between in vivo and in vitro: only axonally transported \\ NGF/p75NTR shows delayed lysosomal accumulation}

Neurotrophins can have different effects, depending on whether they are applied to the axonal target and retrogradely transported along the axon or applied directly to the cell bodies (Deppmann et al., 2008; Mok et al., 2009). To determine whether NGF accumulates in lysosomes with a delay, compared with BDNF, only when applied to the target, we applied radiolabeled NGF or $\mathrm{BDNF}$ to ION pieces maintained in vitro immediately after dissection from chick embryos of the same ages (E14) as used for in vivo studies. After treatment with NGF or BDNF for 1, 2, 3, or $4 \mathrm{~h}$, time intervals that have in previous studies shown lysosomal accumulation when the neurotrophin was applied directly to cell bodies (Claude et al., 1982; Butowt and von Bartheld, 2001), we quantified MVB and lysosomal accumulation by ultrastructural autoradiography (Fig. 6A-C). Morphology of ION tissues was well preserved (Fig. $6 C$ ), in contrast to the poor morphology observed in dissociated ION neurons (data not shown). Lysosomal accumulation of radiolabeled NGF showed a peak at $3 \mathrm{~h}$ (Fig. $6 \mathrm{~A}$ ); this time course is consistent with other in vivo and in vitro studies that applied neurotrophins directly to cell bodies (Claude et al., 1982; Butowt and von Bartheld, 2001). The relatively short time interval compared with our in vivo studies is attributable to direct ION neuron uptake via cell body and dendrites, bypassing the need for axonal transport to the cell body. BDNF accumulated with the same time course in vitro (Fig. $6 \mathrm{~A}$ ): there was no difference between NGF accumulation and BDNF accumulation in lysosomes at any of the four time points examined. These data show that the delayed accumulation of p75NTR-bound NGF after internalization in axon terminals and axonal transport does not occur with application directly to the cell body (in other words, cannot be replicated in vitro). The reason may be either that $\mathrm{p} 75 \mathrm{NTR}$ and/or trkB receptors are differentially expressed between axons and dendrites or cell bodies (unlikely based on immunolabeling experiments of the ION) (von Bartheld and Johnson, 2001), or that target-derived neurotrophins follow and are regulated by different sorting and trafficking mechanisms than cell body- or dendrite-derived neurotrophins, as recently suggested (Deppmann et al., 2008; Mok et al., 2009).

To determine whether accumulation of NGF in lysosomes can be delayed, even when NGF is applied to and internalized by the cell body, we added constitutively active PKC (40 ng) to the incubated ION tissue pieces in vitro, to increase p75NTR phosphorylation, the presumptive signal for delayed accumulation of NGF in lysosomes. As shown in Figure $6 B$, there was a slight, but statistically significant shift $(p<0.05)$ in the timing of lysosomal accumulation, from 3 to $4 \mathrm{~h}$, in the presence of PKC activation. These data are consistent with the notion that somal and dendritic p75NTR can be pharmacologically induced to sort in a similar manner as axonal p75NTR, but the resolution and differentiation are much less distinct than in the axonal in vivo system, because neurotrophins internalize in dendrites (or severed axons) at varying distances from the cell body, thereby obscuring differences in the kinetics of accumulation. We did not attempt to increase PKC activity in our ION model system in vivo, because it is known that pharmacological activation of $\mathrm{PKC}$ inhibits retrograde axonal transport of neurotrophins (Ozsarac et al., 2003).

\section{Endogenous chicken p75NTR is phosphorylated on serine 266}

The results of our mutagenesis and in vitro kinase assays suggest that serine 266 in chick p75NTR is endogenously phosphorylated by conventional $\mathrm{PKC}$, and this posttranslational modification appears to play a role in sorting of p75NTR-ligand complexes after retrograde axonal transport. To verify this, we used mass spectrometry analysis by nano LC/MS/MS to identify amino acid residues that are endogenously phosphorylated in p75NTR. Since commercially available antibodies do not efficiently immunoprecipitate chick p75NTR, we first used a rat PC12 cell line and a well characterized Covance antibody to immunoprecipitate rat p75NTR from these cells. In a second experimental design, we used His-tagged chicken p75NTR purified from transfected HEK293 cells. The primary and secondary peptides derived from samples were analyzed by nano LC/MS/MS on a Micromass Q-Tof 2 and ThermoFisher LTQ. Analyzed samples contained 12 unique peptides (for which fragmentation profiles were determined) for rat p75NTR and 13 unique peptides for chicken p75NTR protein, with sequence coverage in the range of $20-$ $30 \%$. Among the 12 peptides derived from rat p75NTR were 5 that matched the theoretical mass of the region of interest within 

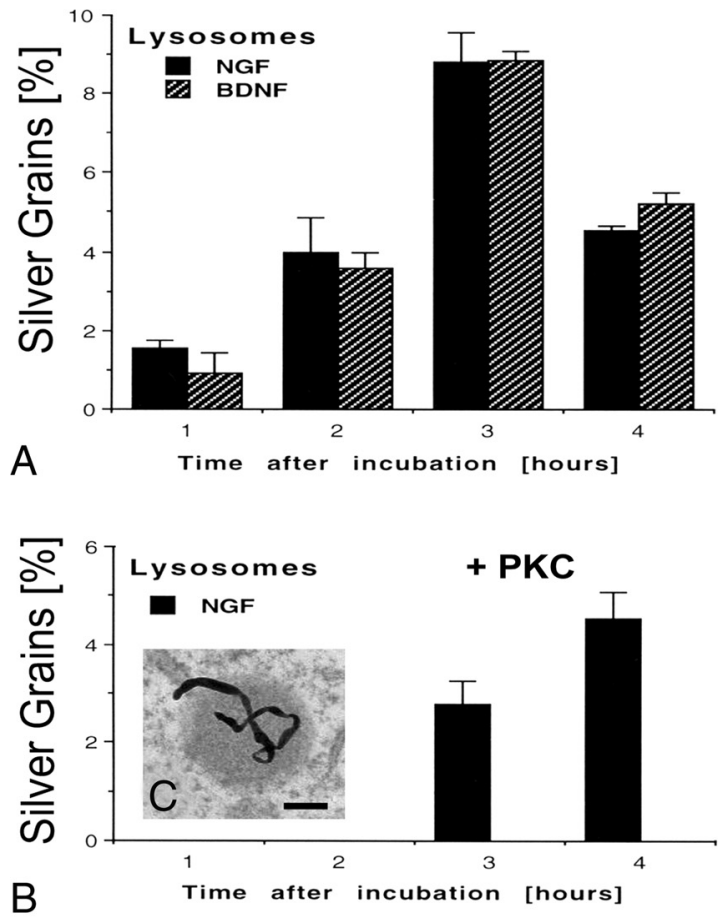

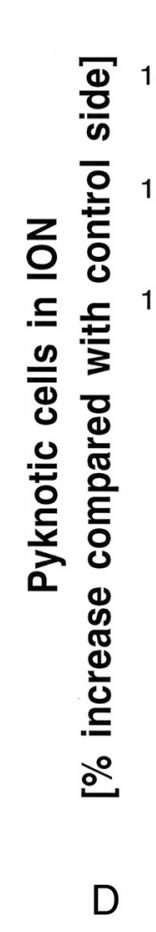

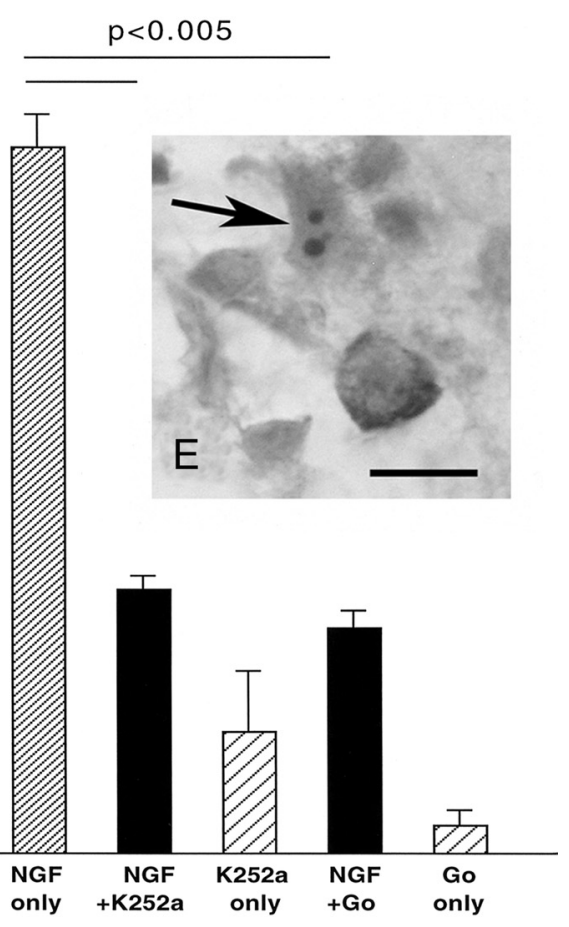

Figure 6. $\boldsymbol{A}-\boldsymbol{E}$, Accumulation of neurotrophins in lysosomes of E14 ION neurons in vitro and effects of NGF and kinase inhibitors on the number of dying neurons in vivo. $\boldsymbol{A}$, Quantification of lysosomal accumulation of silver grains representing radiolabeled NGF and BDNF after $1-4 \mathrm{~h}$ incubation. Error bars indicate SEM. Data are based on three independent experiments with a total of 472 neurons assessed, and 1581 silver grains scored. $B$, Quantification of lysosomal accumulation of NGF in the presence of $40 \mathrm{ng}$ constitutively active conventional PKC after 3 and $4 \mathrm{~h}$. Note the shift in the peak from 3 to $4 \mathrm{~h}$, significantly different from $B$ at $p<0.05$. Error bars indicate SEM. Data are based on three independent experiments with a total of 372 neurons assessed and a total of 913 silver grains scored. C, Inset, Silver grain over a lysosome after internalization of radiolabeled NGF by dendrites or soma at $3 \mathrm{~h}$. Scale bar, $200 \mathrm{~nm}$. $\boldsymbol{D}$, Retina-derived NGF (1 $\mu \mathrm{g}$ per eye) promotes the death of developing ION neurons, as previously reported (von Bartheld et al., 1994; Janiga et al., 2000). Coinjection of either of the kinase inhibitors, K252a or Gö6976 (2 $\mu$ l of 0.25 mm), together with NGF significantly decreases apoptosis of ION neurons. Injection of the kinase inhibitors alone has a significantly smaller effect on apoptosis. Each embryo was injected into the right eye, and the experimental (left) ION was compared with the right ION innervating the noninjected or sham-injected control eye. Error bars indicate SEM. $\boldsymbol{E}$, Inset, Example of a pyknotic cell (arrow) in the ION. Scale bar, $10 \mu \mathrm{m}$.

Table 1. Tryptic peptide sequences of the rat and chicken p75NTR phosphorylated on serines and threonines as detected by nano LC/MS/MS

\begin{tabular}{|c|c|c|c|c|}
\hline Fragment & Calculated mass & Observed mass, average & $\begin{array}{l}\text { Corresponding rat or chicken } \\
\text { p75 fragment }\end{array}$ & $\begin{array}{l}\text { Number of phosphorylations } \\
\text { (serine/threonine) }\end{array}$ \\
\hline \multicolumn{5}{|l|}{ Rat p75NTR (PC12 cells) } \\
\hline QGANSRPVNQTPPPEGEKL & 1986.02 & 1986.09 & $283-302$ & 1 \\
\hline LHSDSGISVDSQSLHDQQTHTQTASGQALKG & 3337.31 & 3336.41 & $301-332$ & 2 \\
\hline GDGNLYSSLPLTK ${ }^{b}$ & 1684.43 & 1685.74 & $332-334$ & 3 \\
\hline ADIVESLCSESTATSPV & 1925.87 & 1925.87 & $410-426$ & 2 \\
\hline WNSCKQNK & 1186.20 & 1187.67 & $276-283$ & 1 \\
\hline \multicolumn{5}{|l|}{ Chicken p75NTR (transfected HEK293 cells) } \\
\hline (R)WNSCK & 773.67 & 774.47 & $264-268$ & 1 \\
\hline GDGSLYASLPPSK & 1512.54 & 1511.93 & $320-332$ & 3 \\
\hline LLSSSAEETWRQLAGELGYK & 2340.74 & 2341.64 & $339-358$ & 2 \\
\hline
\end{tabular}

Phosphorylation of serine within the motif WNSCK (S-266 in chicken and S-278 in rat p75NTR) was detected in both rat and chick p75NTR samples.

${ }^{a}$ Numbering of amino acids in rat and chicken p75NTR includes signal peptide and starts at the first methionine according to Roux and Barker (2002).

${ }^{b}$ Phosphorylated tyrosine was also detected in this peptide.

2.0 Da using the MS3 phospho screen protocol (Table 1). Among the 13 peptides derived from chicken p75NTR were 3 that also matched the theoretical mass of the region of interest using the MS3 phospho screen protocol. This suggests that several serines/ threonines are phosphorylated within the intracellular domain of rat and chicken p75NTR (Table 1). Mass spectroscopy analysis was validated by confirming that serine within the sequence of KLHSD is also endogenously phosphorylated, as reported recently by Higuchi et al. (2003). Moreover, we also detected possible phosphorylation on tyrosine 337 (rat p75NTR), which was previously reported by Ohrt et al. (2004), but had not yet been confirmed by other studies. One of the five identified rat phosphopeptides (WNSCKQNK) and one of three identified chicken phosphopeptides (WNSCK) contains serine 278 (serine 266 in chicken), which is homologous to serine 277 in human p75NTR. Since this tryptic fragment of p75NTR contains only one serine/ threonine, only that amino acid may be phosphorylated. Together, we conclude that serine 266 in chicken p75NTR (and its homologues in mammalian p75NTR) are endogenously phosphorylated and that this phosphorylation plays a key role in regulation of the sorting of axonally transported neurotrophin ligands bound to this receptor. 
Inhibition of endogenous conventional PKC isoforms delays neuronal cell death in the developing ION

Neuronal death in the developing ION has been previously shown to be regulated by target-derived neurotrophins, with BDNF and NT-3 acting as survival factors and NGF and NT-4 acting as death-inducing factors (von Bartheld et al., 1994, 1996b; Primi and Clarke, 1996; Janiga et al., 2000). Interfering with the kinetics of NGF sorting in this system may affect neuronal death within the ION during embryonic development. Therefore, we examined and compared the effects of intraocular injection of NGF alone ( $1 \mu$ g per eye), NGF with K252a ( $1 \mu \mathrm{l}$ at $250 \mu \mathrm{M})$, NGF with the conventional PKC inhibitor Gö6976 (1 $\mu \mathrm{l}$ at $250 \mu \mathrm{M})$, or K252a alone ( $1 \mu \mathrm{l}$ at $250 \mu \mathrm{M})$, or Gö6976 alone $(1 \mu \mathrm{l}$ at $250 \mu \mathrm{M})$ on neuronal cell death in the ION using an established quantification protocol for pyknotic cells (von Bartheld et al., 1994, 1996b; Clarke and Oppenheim, 1995; Janiga et al., 2000) (Fig. $6 D, E)$. The contralateral ION for each embryo (age E13-E14) was used for the experimental side, and the ipsilateral ION was used as an internal control. Consistent with previous work (Janiga et al., 2000), $24 \mathrm{~h}$ after injections, NGF induced approximately twice $(+120 \%)$ the level of cell death compared with the ipsilateral control side $(p<0.005)$ (Fig. 6D). However, coinjection of NGF with Gö6976 decreased the relative cell death ratio in the experimental ION to approximately $+40 \%$ compared with the ipsilateral side $(p<0.005)$ (Fig. $6 D)$. Injection of inhibitors alone had no significant effect on neuronal cell death in the developing ION (Fig. 6D). These data suggest that inhibition of conventional PKC alters the sorting pathway of NGF by accelerating its signaling/degradation kinetics in ION cell bodies and thus caused increased survival of neurons. The mechanism of this process apparently involves changes in the phosphorylation status of p75NTR.

\section{Discussion}

We propose that regulation of signal duration, measured by accumulation of neurotrophins in degradative organelles (lysosomes), plays a significant role in apoptosis signaling, and that such lysosomal sorting is regulated by phosphorylation of axonally transported p75NTR.

\section{Neurotrophins translocate from p75NTR to trks during retrograde transport}

Previous work suggested, but did not prove, that neurotrophins remain bound to receptors during axonal transport (Ehlers et al., 1995; Watson et al., 1999; Ye et al., 2003; Hibbert et al., 2006). We show that both $\mathrm{p} 75 \mathrm{NTR}$ and trkB receptors contribute to the retrograde axonal transport of BDNF from the retina to the ION. Intriguingly, the binding of BDNF to trkB/C and to p75NTR is dynamic during retrograde axonal transport. After internalization in the retina, a relatively large fraction of BDNF binds to p75NTR, but at the level of the ION, a significant fraction of BDNF appears to have translocated from p75NTR to trkB during or after axonal transport. An alternative scenario, that trkB becomes "expelled" from an initial ternary complex, appears unlikely, because neurotrophins, trks, and p75NTR receptors do not form such a complex (Wehrman et al., 2007; Gong et al., 2008). This suggests that at least some BDNF switches from p75NTR to trkB during transport, a phenomenon that would explain enhanced effects of neurotrophins in the presence of both receptor types, without evoking the need for an elusive trk-p75NTR highaffinity binding site. Previous experiments, using a fluorescence approach, indicated that trk receptors are cotransported with their ligands; however, those experiments were not designed to reveal a transfer of ligands between receptors during retrograde transport (Watson et al., 1999; Delcroix et al., 2003; Hibbert et al., 2006). A transfer of BDNF from $\mathrm{p} 75 \mathrm{NTR}$ and gradual concentration of BDNF on trkB during axonal transport of the signaling endosome is consistent with known ligand association/dissociation rates of BDNF for p75NTR and trkB receptors (RodriguezTébar and Barde, 1988; Bothwell, 1995; Chao and Hempstead, 1995 ) and survival function of BDNF in this system (von Bartheld et al., 1994). Transfer of neurotrophin ligands from p75NTR to trk receptors may be an important function of p75NTR-trk cooperation in vivo (Bothwell, 1995; Chao and Hempstead, 1995; Roux and Barker, 2002).

\section{Differences in signal duration (ligand degradation) between p75NTR and trk ligands}

The presence of $\mathrm{p} 75 \mathrm{NTR}$ in a recycling compartment, and trks in a degradative pathway, was recently reported on internalization of neurotrophins along the cell surface in vitro (Bronfman et al., 2003; Saxena et al., 2005). These reports suggested that p75NTRligand complexes are degraded with a delay when compared with trk-ligand complexes, as suggested previously (Ure and Campenot, 1997). The present study confirms this notion, but extends previous studies by examining neurotrophins that had been retrogradely transported in an in vivo model, and at higher resolution.

By using highly sensitive quantitative autoradiography at the ultrastructural level, we show that survival-promoting, trkbinding neurotrophins (BDNF and NT-3) progress through the degradation pathway in vivo with different kinetics than the death-promoting, p75NTR-binding NGF. BDNF and NT-3 accumulate much earlier than NGF within organelles of the sorting and ligand-sequestering pathway-in MVBs and in the degradative pathway (lysosomes). This difference is not attributable to different rates of axonal transport, since we here and others (Hibbert et al., 2006) recently showed that p75NTR-mediated retrograde axonal transport has a similar speed when compared with trk-mediated movement. It is currently not known to what extent proNGF may contribute as an endogenous ligand for p75NTR in the retina, and whether it may form a complex with the coreceptor sortilin (Jansen et al., 2007). Nevertheless, since neurotrophins in ION axons use p75NTR and trk receptors during retrograde transport, these receptors appear to regulate their differential sorting. Sorting into MVBs is believed to terminate signaling, since the cytoplasmic domain of the receptor is secluded from its signaling partners (Sorkin and von Zastrow, 2002; Wu et al., 2009), and BDNF resides primarily in the internal vesicles within MVBs after retrograde transport to the cell body (Rind et al., 2005). Therefore, the time interval during which endosomes are available for signaling within the cell body (before signal termination by sequestration into MVBs) may be critical for the extent of survival or death signaling.

\section{Kinase activity modulates sequestration of p75NTR-ligands in MVBs and degradation}

Regulated phosphorylation of growth factor receptors (Felder et al., 1990; Bao et al., 2000) and other signaling proteins (Nakata and Kamiguchi, 2007) plays a key role in the control of membrane trafficking along endocytic pathways in non-neuronal (Sieczkarski et al., 2003; Lladó et al., 2004; Lindmo and Stenmark, 2006) and neuronal systems (Ehlers, 2000; Martin and Henley, 2004). The intracellular domain of p75NTR can be robustly phosphorylated (Grob et al., 1985; Taniuchi et al., 1986), yet the in vivo function of this posttranslational modification and the 
responsible kinases were not identified (Roux and Barker, 2002). The indolecarbazole derivative K252a is a potent trk inhibitor (Berg et al., 1992), but as a nonselective ATP competitive inhibitor, it can inhibit the activity of several other kinases such as mixed lineage kinases 1/3 (Murakata et al., 2002; Roux et al., 2002), PKA, and PKC (Kase et al., 1987; Rüegg and Burgess, 1989). The PKC family is known to regulate receptor internalization, receptor desensitization, and membrane trafficking (Lladó et al., 2004; Idkowiak-Baldys et al., 2006; Alvi et al., 2007).

We first examined the effects of the commonly used trk tyrosine kinase inhibitor, K252a, to inhibit the activity of trkB and trkC in our system, since "global" trk inhibition can interfere with sorting of trk-bound neurotrophins (Butowt and von Bartheld, 2001; Saxena et al., 2005). In the ION model, trk inhibition that originated in the target did not change the distribution and sorting of retrogradely transported BDNF and NT-3. However, the kinetics of NGF sorting shifted toward significantly faster accumulation in the organelles of the MVB sequestering and degradation pathways. Since the ION does not express trkA, the effect of K252a on NGF sorting in the ION soma cannot be attributable to direct trk inhibition. In support of this notion, the tyrosine kinase inhibitor genistein-which has minimal effects on PKC- did not alter NGF sorting. Since NGF binds exclusively to p75NTR in our ION model, these data suggest that the PKC family may be involved in the phosphorylation of the intracellular portion of the p75NTR and in the sorting process.

\section{Chicken p75NTR is phosphorylated on serine 266 by conventional PKC}

Phosphorylation of p75NTR by PKA has been reported to regulate receptor localization to lipid rafts (Higuchi et al., 2003). Our mutagenesis and in vitro phosphorylation data identified conventional PKC as another candidate among kinases that phosphorylate p75NTR. Conventional PKC phosphorylates an evolutionarily conserved serine within the juxtamembrane motif (KRWNSCKQ; S-266 in chick, S-277 in human). This sequence has 100\% homology between mammalian, avian, and Xenopus p75NTR, which suggests an important physiological function. The theoretical prediction of phosphorylation sites within p75NTR using the NetPhos algorithm supports our experimental data and shows that S-277 is located within the PKC-specific consensus sequence and has a $>95 \%$ probability of being phosphorylated. Mass spectroscopic data confirm that this particular serine is phosphorylated in vivo in both chicken and mammalian p75NTR.

Using the potent conventional PKC inhibitor, Gö6976 (Biswas et al., 2001; Sivasankaran et al., 2004), we observed a similar shift of degradation kinetics for NGF as seen after K252a application. Since all four conventional PKC isoforms are commonly expressed in neurons and isoform-specific inhibitors are currently not available, we cannot identify which of them phosphorylate endogenous p75NTR or which signal transduction pathways are engaged upstream of PKC to activate the kinase.

Together, our data indicate that conventional PKC kinase(s) regulate endocytic sorting of retrogradely transported p75NTR by phosphorylating the conserved serine 266 residue (S-277 in human) within the juxtamembrane region. This phosphorylation leads to slower sequestering of the signaling endosome in MVBs and/or slower degradation compared with trk-bound ligands. We propose that this mechanism controls the duration of signaling of p75NTR-ligand complexes after retrograde transport to the cell body.
Neurotrophins have well established prosurvival (BDNF and NT-3) and proapoptotic functions (NGF) in the developing ION (von Bartheld et al., 1994; Janiga et al., 2000). Our study shows that interfering with the sorting of p75NTR-ligands affects the biological role of the ligands in this system. Pharmacological inhibition of conventional PKC in the target significantly rescues embryonic chick ION neurons in vivo from the downstream effects of the target-applied "killer" NGF. This appears to be mediated by accelerated sequestering of NGF in MVBs and accumulation of NGF in the degradation pathway, thus leading to a shortening (decrease) of death signaling via p75NTR-NGF in the cell body. We conclude that manipulation of phosphorylation events affects not only trk signaling (Berg et al., 1992), but also p75NTR signaling. Furthermore, the precise mechanisms of previously observed effects of kinase inhibitors such as K252a on survival signaling may be more complex than previously appreciated. Our findings may provide new avenues for drug development with therapeutic implications for the rescue of neurons.

\section{References}

Altick AL, Baryshnikova LM, Vu TQ, von Bartheld CS (2009) Quantitative analysis of multivesicular bodies (MVBs) in the hypoglossal nerve: evidence that neurotrophic factors do not use MVBs for retrograde axonal transport. J Comp Neurol 514:641-657.

Alvi F, Idkowiak-Baldys J, Baldys A, Raymond JR, Hannun YA (2007) Regulation of membrane trafficking and endocytosis by protein kinase C: emerging role of the pericentrion, a novel protein kinase $\mathrm{C}$-dependent subset of recycling endosomes. Cell Mol Life Sci 64:263-270.

Bao J, Alroy I, Waterman H, Schejter ED, Brodie C, Gruenberg J, Yarden Y (2000) Threonine phosphorylation diverts internalized epidermal growth factor receptors from a degradative pathway to the recycling endosome. J Biol Chem 275:26178-26186.

Barde YA (1989) Trophic factors and neuronal survival. Neuron 2:1525-1534.

Barker PA, Murphy RA (1992) The nerve growth factor receptor: a multicomponent system that mediates the actions of the neurotrophin family of proteins. Mol Cell Biochem 110:1-15.

Berg MM, Sternberg DW, Parada LF, Chao MV (1992) K-252a inhibits nerve growth factor-induced trk proto-oncogene tyrosine phosphorylation and kinase activity. J Biol Chem 267:13-16.

Biswas DK, Dai SC, Cruz A, Weiser B, Graner E, Pardee AB (2001) The nuclear factor kappa B (NF-kappa B): a potential therapeutic target for estrogen receptor negative breast cancers. Proc Natl Acad Sci U S A 98:10386-10391.

Bos K, Wraight C, Stanley KK (1993) TGN38 is maintained in the transGolgi network by a tyrosine-containing motif in the cytoplasmic domain. EMBO J 12:2219-2228.

Bothwell M (1995) Functional interactions of neurotrophins and neurotrophin receptors. Annu Rev Neurosci 18:223-253.

Bronfman FC, Tcherpakov M, Jovin TM, Fainzilber M (2003) Ligandinduced internalization of the p75 neurotrophin receptor: a slow route to the signaling endosome. J Neurosci 23:3209-3220.

Bronfman FC, Escudero CA, Weis J, Kruttgen A (2007) Endosomal transport of neurotrophins: roles in signaling and neurodegenerative diseases. Dev Neurobiol 67:1183-1203.

Butowt R, von Bartheld CS (2001) Sorting of internalized neurotrophins into an endocytic transcytosis pathway via the Golgi system: ultrastructural analysis in retinal ganglion cells. J Neurosci 21:8915-8930.

Butowt R, von Bartheld CS (2003) Connecting the dots: trafficking of neurotrophins, lectins and diverse pathogens by binding to the neurotrophin receptor p75NTR. Eur J Neurosci 17:673-680.

Butowt R, von Bartheld CS (2005) Anterograde axonal transport of BDNF and NT-3 by retinal ganglion cells: roles of neurotrophin receptors. Mol Cell Neurosci 29:11-25.

Carter BD, Lewin GR (1997) Neurotrophins live or let die: does p75NTR decide? Neuron 18:187-190.

Chao MV, Hempstead BL (1995) p75 and Trk: a two-receptor system. Trends Neurosci 18:321-326.

Clarke PG (1992) Neuron death in the developing avian isthmo-optic nu- 
cleus, and its relation to the establishment of functional circuitry. J Neurobiol 23:1140-1158.

Clarke PG, Oppenheim RW (1995) Neuron death in vertebrate development: in vitro methods. Methods Cell Biol 46:277-321.

Clarke PG, Posada A, Primi MP, Castagné V (1998) Neuronal death in the central nervous system during development. Biomed Pharmacother $52: 356-362$.

Claude P, Hawrot E, Dunis DA, Campenot RB (1982) Binding, internalization, and retrograde transport of 125I-nerve growth factor in cultured rat sympathetic neurons. J Neurosci 2:431-442.

Curtis R, Adryan KM, Stark JL, Park JS, Compton DL, Weskamp G, Huber LJ, Chao MV, Jaenisch R, Lee KF (1995) Differential role of the low affinity neurotrophin receptor (p75) in retrograde axonal transport of the neurotrophins. Neuron 14:1201-1211.

Dechant G, Barde YA (2002) The neurotrophin receptor p75(NTR): novel functions and implications for diseases of the nervous system. Nat Neurosci 5:1131-1136.

Delcroix JD, Valletta JS, Wu C, Hunt SJ, Kowal AS, Mobley WC (2003) NGF signaling in sensory neurons: evidence that early endosomes carry NGF retrograde signals. Neuron 39:69-84.

Deppmann CD, Mihalas S, Sharma N, Lonze BE, Niebur E, Ginty DD (2008) A model for neuronal competition during development. Science 320:369-373.

Ehlers MD (2000) Reinsertion or degradation of AMPA receptors determined by activity-dependent endocytic sorting. Neuron 28: 511-525.

Ehlers MD, Kaplan DR, Price DL, Koliatsos VE (1995) NGF-stimulated retrograde transport of trkA in the mammalian nervous system. J Cell Biol 130:149-156.

Escandón E, Burton LE, Szönyi E, Nikolics K (1993) Characterization of neurotrophin receptors by affinity crosslinking. J Neurosci Res 34:601-613.

Felder S, Miller K, Moehren G, Ullrich A, Schlessinger J, Hopkins CR (1990) Kinase activity controls the sorting of the epidermal growth factor receptor within the multivesicular body. Cell 61:623-634.

Frade JM, Barde YA (1998) Nerve growth factor: two receptors, multiple functions. Bioessays 20:137-145.

Garner AS, Menegay HJ, Boeshore KL, Xie XY, Voci JM, Johnson JE, Large $\mathrm{TH}$ (1996) Expression of TrkB receptor isoforms in the developing avian visual system. J Neurosci 16:1740-1752.

Gong Y, Cao P, Yu HJ, Jiang T (2008) Crystal structure of the neurotrophin-3 and p75NTR symmetrical complex. Nature 454:789-793.

Grob PM, Ross AH, Koprowski H, Bothwell M (1985) Characterization of the human melanoma nerve growth factor receptor. J Biol Chem 260:8044-8049.

Hallböök F, Bäckström A, Kullander K, Ebendal T, Carri NG (1996) Expression of neurotrophins and trk receptors in the avian retina. J Comp Neurol 364:664-676.

Hamburger V, Hamilton H (1951) A series of normal stages in the development of the chick embryo. J Morphol 88:49-92.

Herzog KH, von Bartheld CS (1998) Contributions of the optic tectum and the retina as sources of brain-derived neurotrophic factor for retinal ganglion cells in the chick embryo. J Neurosci 18:2891-2906.

Heuer JG, Fatemie-Nainie S, Wheeler EF, Bothwell M (1990) Structure and developmental expression of the chicken NGF receptor. Dev Biol 137:287-304.

Hibbert AP, Kramer BM, Miller FD, Kaplan DR (2006) The localization, trafficking and retrograde transport of BDNF bound to p75NTR in sympathetic neurons. Mol Cell Neurosci 32:387-402.

Higuchi H, Yamashita T, Yoshikawa H, Tohyama M (2003) PKA phosphorylates the p75 receptor and regulates its localization to lipid rafts. EMBO J 22:1790-1800.

Idkowiak-Baldys J, Becker KP, Kitatani K, Hannun YA (2006) Dynamic sequestration of the recycling compartment by classical protein kinase C. J Biol Chem 281:22321-22331.

Janiga TA, Rind HB, von Bartheld CS (2000) Differential effects of the trophic factors BDNF, NT-4, GDNF, and IGF-I on the isthmo-optic nucleus in chick embryos. J Neurobiol 43:289-303.

Jansen P, Giehl K, Nyengaard JR, Teng K, Lioubinski O, Sjoegaard SS, Breiderhoff T, Gotthardt M, Lin F, Eilers A, Petersen CM, Lewin GR, Hempstead BL, Willnow TE, Nykjaer A (2007) Roles for the pro- neurotrophin receptor sortilin in neuronal development, aging and brain injury. Nat Neurosci 10:1449-1457.

Jinsi-Parimoo A, Deth RC (2000) Protein kinase C-dependent coupling of alpha(2A/D)-adrenergic receptors to phospholipase D. Pharmacology 60:19-26.

Kase H, Iwahashi K, Nakanishi S, Matsuda Y, Yamada K, Takahashi M, Murakata C, Sato A, Kaneko M (1987) K-252 compounds, novel and potent inhibitors of protein kinase $\mathrm{C}$ and cyclic nucleotide-dependent protein kinases. Biochem Biophys Res Commun 142:436-440.

Koizumi S, Contreras ML, Matsuda Y, Hama T, Lazarovici P, Guroff G (1988) K-252a: a specific inhibitor of the action of nerve growth factor on PC 12 cells. J Neurosci 8:715-721.

Large TH, Weskamp G, Helder JC, Radeke MJ, Misko TP, Shooter EM, Reichardt LF (1989) Structure and developmental expression of the nerve growth factor receptor in the chicken central nervous system. Neuron 2:1123-1134.

Lazarovici P, Jiang H, Fink D Jr (1998) The 38-amino-acid form of pituitary adenylate cyclase-activating polypeptide induces neurite outgrowth in PC12 cells that is dependent on protein kinase $\mathrm{C}$ and extracellular signalregulated kinase but not on protein kinase $\mathrm{A}$, nerve growth factor receptor tyrosine kinase, $\mathrm{p} 21$ (ras) $\mathrm{G}$ protein, and pp60(c-src) cytoplasmic tyrosine kinase. Mol Pharmacol 54:547-558.

Lefcort F, Clary DO, Rusoff AC, Reichardt LF (1996) Inhibition of the NT-3 receptor TrkC, early in chick embryogenesis, results in severe reductions in multiple neuronal subpopulations in the dorsal root ganglia. J Neurosci 16:3704-3713.

Lindmo K, Stenmark H (2006) Regulation of membrane traffic by phosphoinositide 3-kinases. J Cell Sci 119:605-614.

Lladó A, Tebar F, Calvo M, Moretó J, Sorkin A, Enrich C (2004) Protein kinaseCdelta-calmodulin crosstalk regulates epidermal growth factor receptor exit from early endosomes. Mol Biol Cell 15:4877-4891.

Marshall CJ (1995) Specificity of receptor tyrosine kinase signaling: transient versus sustained extracellular signal-regulated kinase activation. Cell 80:179-185.

Martin S, Henley JM (2004) Activity-dependent endocytic sorting of kainate receptors to recycling or degradation pathways. EMBO J 23:4749-4759.

Mok SA, Campenot RB (2007) A nerve growth factor-induced retrograde survival signal mediated by mechanisms downstream of TrkA. Neuropharmacology 52:270-278.

Mok SA, Lund K, Campenot RB (2009) A retrograde apoptotic signal originating in NGF-deprived distal axons of rat sympathetic neurons in compartmented cultures. Cell Res 19:546-560.

Murakata C, Kaneko M, Gessner G, Angeles TS, Ator MA, O’Kane TM, McKenna BA, Thomas BA, Mathiasen JR, Saporito MS, Bozyczko-Coyne D, Hudkins RL (2002) Mixed lineage kinase activity of indolocarbazole analogues. Bioorg Med Chem Lett 12:147-150.

Nakata A, Kamiguchi H (2007) Serine phosphorylation by casein kinase II controls endocytic L1 trafficking and axon growth. J Neurosci Res 85:723-734.

Ohrt T, Mancini A, Tamura T, Niedenthal R (2004) c-Cbl binds to tyrosine phosphorylated neurotrophin receptor p75 and induces its ubiquitination. Cell Signal 16:1291-1298.

Oppenheim RW, von Bartheld CS (2008) Programmed cell death and neurotrophic factors. In: Fundamental neuroscience, Ed 3 (Squire LR, Berg D, Bloom F, du Lac S, Ghosh A, eds), pp 437-467. San Diego: Elsevier.

Opresko LK, Chang CP, Will BH, Burke PM, Gill GN, Wiley HS (1995) Endocytosis and lysosomal targeting of epidermal growth factor receptors are mediated by distinct sequences independent of the tyrosine kinase domain. J Biol Chem 270:4325-4333.

Ozsarac N, Weible M 2nd, Reynolds AJ, Hendry IA (2003) Activation of protein kinase $\mathrm{C}$ inhibits retrograde transport of neurotrophins in mice. J Neurosci Res 72:203-210.

Peters A, Palay SL, Webster HdF (1991) The fine structure of the nervous system, Ed 3. New York: Oxford UP.

Primi MP, Clarke PGH (1996) Retrograde neurotrophin-mediated control of neurone survival in the developing central nervous system. Neuroreport 7:473-476.

Purves D (1988) Body and brain. A trophic theory of neural connections. Cambridge, MA: Harvard UP.

Rind HB, Butowt R, von Bartheld CS (2005) Synaptic targeting of retrogradely transported trophic factors in motoneurons: comparison of glial 
cell line-derived neurotrophic factor, brain-derived neurotrophic factor, and cardiotrophin-1 with tetanus toxin. J Neurosci 25:539-549.

Rodriguez-Tébar A, Barde YA (1988) Binding characteristics of brainderived neurotrophic factor to its receptors on neurons from the chick embryo. J Neurosci 8:3337-3342.

Roux PP, Barker PA (2002) Neurotrophin signaling through the p75 neurotrophin receptor. Prog Neurobiol 67:203-233.

Roux PP, Dorval G, Boudreau M, Angers-Loustau A, Morris SJ, Makkerh J, Barker PA (2002) K252a and CEP1347 are neuroprotective compounds that inhibit mixed-lineage kinase-3 and induce activation of Akt and ERK. J Biol Chem 277:49473-49480.

Rüegg UT, Burgess GM (1989) Staurosporine, K-252 and UCN-01: potent but nonspecific inhibitors of protein kinases. Trends Pharmacol Sci 10:218-220.

Saxena S, Howe CL, Cosgaya JM, Steiner P, Hirling H, Chan JR, Weis J, Krüttgen A (2005) Differential endocytic sorting of p75NTR and TrkA in response to NGF: a role for late endosomes in TrkA trafficking. Mol Cell Neurosci 28:571-587.

Sieczkarski SB, Brown HA, Whittaker GR (2003) Role of protein kinase C betaII in influenza virus entry via late endosomes. J Virol 77:460-469.

Sivasankaran R, Pei J, Wang KC, Zhang YP, Shields CB, Xu XM, He Z (2004) PKC mediates inhibitory effects of myelin and chondroitin sulfate proteoglycans on axonal regeneration. Nat Neurosci 7:261-268.

Sorkin A, von Zastrow M (2002) Signal transduction and endocytosis: close encounters of many kinds. Nat Rev Mol Cell Biol 3:600-614.

Strohmaier C, Carter BD, Urfer R, Barde YA, Dechant G (1996) A splice variant of the neurotrophin receptor trkB with increased specificity for brain-derived neurotrophic factor. EMBO J 15:3332-3337.

Taniuchi M, Johnson EM Jr, Roach PJ, Lawrence JC Jr (1986) Phosphorylation of nerve growth factor receptor proteins in sympathetic neurons and PC12 cells. In vitro phosphorylation by the cAMP-independent protein kinase FA/GSK-3. J Biol Chem 261:13342-13349.

Traverse S, Gomez N, Paterson H, Marshall C, Cohen P (1992) Sustained activation of the mitogen-activated protein (MAP) kinase cascade may be required for differentiation of PC12 cells. Comparison of the effects of nerve growth factor and epidermal growth factor. Biochem J 288:351-355.

Ure DR, Campenot RB (1997) Retrograde transport and steady-state distribution of ${ }^{125} \mathrm{I}$-nerve growth factor in rat sympathetic neurons in compartmented cultures. J Neurosci 17:1282-1290.

von Bartheld CS (2001) Tracing with radiolabeled neurotrophins. Methods Mol Biol 169:195-216.

von Bartheld CS, Johnson JE (2001) Target-derived BDNF (brain-derived neurotrophic factor) is essential for the survival of developing neurons in the isthmo-optic nucleus. J Comp Neurol 433:550-564.

von Bartheld CS, Heuer JG, Bothwell M (1991) Expression of nerve growth factor (NGF) receptors in the brain and retina of chick embryos: comparison with cholinergic development. J Comp Neurol 310:103-129.

von Bartheld CS, Kinoshita Y, Prevette D, Yin QW, Oppenheim RW, Bothwell M (1994) Positive and negative effects of neurotrophins on the isthmo-optic nucleus in chick embryos. Neuron 12:639-654.

von Bartheld CS, Byers MR, Williams R, Bothwell M (1996a) Anterograde transport and axo-dendritic transfer of neurotrophins in the developing visual system. Nature 379:830-833.

von Bartheld CS, Williams R, Lefcort F, Clary DO, Reichardt LF, Bothwell M (1996b) Retrograde transport of neurotrophins from the eye to the brain in chick embryos: roles of the $\mathrm{p} 75^{\mathrm{NTR}}$ and trkB receptors. J Neurosci 16:2995-3008.

von Bartheld CS, Rind HB, Guglielmo ES, Butowt R (2004) Fates of retrogradely transported proteins: degradation or recycling? Int J Dev Neurosci 22:621.

Wan J, Cheung AY, Fu WY, Wu C, Zhang M, Mobley WC, Cheung ZH, Ip NY (2008) Endophilin B1 as a novel regulator of nerve growth factor/TrkA trafficking and neurite outgrowth. J Neurosci 28:9002-9012.

Watson FL, Heerssen HM, Moheban DB, Lin MZ, Sauvageot CM, Bhattacharyya A, Pomeroy SL, Segal RA (1999) Rapid nuclear responses to target-derived neurotrophins require retrograde transport of ligand-receptor complex. J Neurosci 19:7889-7900.

Wehrman T, He X, Raab B, Dukipatti A, Blau H, Garcia KC (2007) Structural and mechanistic insights into nerve growth factor interactions with the TrkA and p75 receptors. Neuron 53:25-38.

Weible MW 2nd, Bartlett SE, Reynolds AJ, Hendry IA (2001) Prolonged recycling of internalized neurotrophins in the nerve terminal. Cytometry 43:182-188.

Weskamp G, Reichardt LF (1991) Evidence that biological activity of NGF is mediated through a novel subclass of high affinity receptors. Neuron 6:649-663.

Wu C, Cui B, He L, Chen L, Mobley WC (2009) The coming of age of axonal neurotrophin signaling endosomes. J Proteomics 72:46-55.

Ye H, Kuruvilla R, Zweifel LS, Ginty DD (2003) Evidence in support of signaling endosome-based retrograde survival of sympathetic neurons. Neuron 39:57-68.

Zweifel LS, Kuruvilla R, Ginty DD (2005) Functions and mechanisms of retrograde neurotrophin signalling. Nat Rev Neurosci 6:615-625. 